\title{
Filosofia da ciência e evolução: uma contribuição ao ensino Parte 3. Por que evolução?
}

\author{
Francisco José de Figueiredo \\ Doutor em Ciências Biológicas (UFRJ), Professor Associado do Departamento de Zoologia (UERJ) \\ $\triangle$ fjfig@globo.com \\ Levy Aquino de Oliveira \\ Graduando em Ciências Biológicas (UERJ), Monitor da disciplina de Evolução do curso de graduação \\ em Ciências Biológicas (UERJ) \\ $\square$ levyaquino2009@hotmail.com
}

Recebido em 6 de junho de 2020

Aceito em 26 de julho de 2020

\section{Resumo:}

A ciência, como uma entre várias formas do saber, se destaca por apresentar rigorosos métodos de investigação da realidade objetiva. Conhecer a natureza da ciência, suas potencialidades e limites, é pré-requisito para distingui-la de formas rivais de conhecimento e avaliar sua eficácia. Isto contribui para uma análise crítica de diferentes propostas difusas na sociedade como tentativas para descrição e explicação do mundo físico. Entre elas estão àquelas ligadas às origens, como a história da biodiversidade no planeta Terra. Nesse artigo, a demarcação entre ciência e não ciência é explorada. Uma vez que há diferentes tipos de ciências ("hards" and "softs), com diferentes metodologias, a questão demarcatória permanece problemática. O critério de vulnerabilidade se apresenta como eficiente nas ciências históricas em que os indivíduos naturais recebem papel importante. Porém, justificativas subjacentes podem levar a uma condição de indesejável regressão infinita. Com o intuito de se avaliar o status científico da teoria evolutiva, aspectos conceituais são apresentados comparativamente em contexto histórico e filosófico, desde o início da Neosíntese até sua atual versão estendida. Grandes transições e rupturas epistemológicas são discutidas e seus impactos, avaliados. Dentro da metodologia encaminhada por Imre Lakatos, a teoria evolutiva constitui um programa de investigação científica progressivo, gerando diversas predições testáveis e acumulando evidências. A teoria tem sofrido reformulações recentes acomodando diversas novidades, entre elas a revolução da biologia molecular e biologia do desenvolvimento. Apesar das controvérsias e do polifiletismo conceitual quanto aos processos evolutivos envolvidos, a Neosíntese mostra-se resiliente, permanecendo como a melhor explicação para a história da biodiversidade no planeta Terra.

Palavras-chave: Filosofia da Ciência, Método científico, Darwinismo, Ensino de Biologia, Neosíntese.

\section{Philosophy of science and evolution: a contribution to the science teaching Part 3. Why evolution?}

\begin{abstract}
:
Science as one of many ways of knowing stands out for producing rigorous methods to investigate objective reality. Knowing nature of science, its potentialities and limits, it is a precondition to distinguish it from many rival proposes and to evaluate its efficacy. It contributes for a critical analysis of many diffuse conjectures in the society concerning description and explanation of physical world, among them that about origins, as the case of history of biodiversity in the Earth. Herein, the problem of demarcation of science is dealt. Since there are so many sciences ("softs" and "hards") with different methodologies, demarcation issues remain problematic. The criterion of vulnerability seems to be more adequate for historical sciences whose natural individual matters as objects of study.
\end{abstract}


However, underlying justifications could lead up to undesirable infinite regression. With the purpose for evaluating the scientific status of the theory of evolution, conceptual aspects are comparatively analyzed in historical and philosophical contexts, since the beginnings of neosynthesis to actual extended version. Great transitions and epistemological ruptures are discussed and their impacts evaluated. Within the Lakatos' methodology for scientific research, the theory of evolution constitutes a progressive program, generating many testable predictions and accumulating evidences. This theory has been modified to accommodate new data, among them those coming from molecular biology and biology of development. Besides controversies and polyphyletic concepts regarding evolutionary process, Neosynthesis remains as the better explanation for the history of the biodiversity in the Earth.

Keywords: Philosophy of Science, Scientific method, Darwinism, Science teaching, Neosynthesis.

\section{Filosofía de la ciencia y evolución: una contribución a la enseñanza de ciencias Parte 3. ¿Por qué la evolución?}

\section{Resumen:}

La ciencia, como una de varias formas de conocimiento, se destaca por presentar métodos rigurosos de investigación de la realidad objetiva. Conocer a la naturaleza de la ciencia, sus potenciales y límites, es un requisito previo para distinguirla de las formas rivales de conocimiento y evaluar su efectividad. Esto contribuye a un análisis crítico de diferentes propuestas difusas en la sociedad como intentos de describir y explicar el mundo físico. Entre ellos están aquellos vinculados a los orígenes, como la historia de la biodiversidad en el planeta Tierra. En este articulo, se explora la demarcación entre ciencia y no ciencia. Dado que existen diferentes tipos de ciencias ("hards" y "softs"), con diferentes metodologías, el tema de la demarcación sigue siendo problemático. El criterio de vulnerabilidad se presenta como eficiente en las ciencias históricas en las que los individuos naturales tienen un papel importante. Sin embargo, las justificaciones subyacentes pueden conducir a una condición de regresión infinita indeseable. Para evaluar el estado científico de la teoría evolutiva, los aspectos conceptuales se presentan comparativamente en el contexto histórico y filosófico, desde el comienzo de la Neosíntesis hasta su versione xtendida actual. Se discuten las principales transiciones y rupturas epistemológicas y se evalúan sus impactos. Dentro de la metodología proporcionada por Imre Lakatos, la teoría evolutiva constituye un programa de investigación científica progresivo, que genera varias predicciones testabiles y acumula evidencia. La teoría ha sufrido recientes reformulaciones que acomodan varias novedades, entre ellas la revolución de la biología molecular y la biología del desarrollo. A pesar de las controversia y el polifiletismo conceptual con respecto a los procesos evolutivos involucrados, la Neosíntesis demuestra ser resiliente, sendo la mejor explicación para la historia de la biodiversidad en el planeta Tierra.

Palabras clave: Filosofía de la ciencia, Método científico, Darwinismo, Enseñanza de las ciencias, Neosíntesis.

\section{INTRODUÇÃO}

FIGUEIREDO e OLIVEIRA (in press, 1 e 2) enfatizaram a importância da filosofia da ciência e da natureza da ciência como pré-requisitos para a compreensão do metafenômeno evolutivo. Também salientaram que, antes de qualquer coisa, entender como a ciência opera, seus limites e vantagens, dá ao cidadão oportunidade para melhor julgar memes que são continua e repetidamente difundidos como verdades na sociedade. Senso crítico e natureza 
da ciência estão inter-relacionados. Falsas verdades, particularmente aquelas vindas das pseudociências, afetam diretamente a qualidade de vida das pessoas, suas atitudes e até seus gastos financeiros (PIGLIUCCI, 2013). Além da confusão gerada na sociedade, elas movimentam atividades financeiras diversas que se alimentam da ignorância alheia e os danos causados podem ser imensos.

Nesse artigo, o problema da demarcação entre ciência e pseudociência é brevemente apresentado e discutido. Desde a formalização do "problema da demarcação" feito por Karl Popper, na metade do século XX, a discussão continua (POPPER, 1972; MAGEE, 1974; SOBER, 1993, 2008; ROSENBERG e MCSHEA, 2008; PIGLIUCCI, 2013; PIGLIUCCI e BOUDRY, 2013). A receita prescrita por Popper para tentar separar ciência de pseudociência foi o critério da falsificabilidade, mas sua aceitação não foi consensual (HULL, 1987; HULL e RUSE, 1998; SOBER, 2008). Diversos aspectos corrompem a proposta tendo em vista a existência de diferentes ciências ("softs" e "hards") e métodos científicos, pouco ou muito eficientes (FIGUEIREDO e OLIVEIRA, in press).

Num autêntico "vale-tudo", as pseudociências continuaram a se propagar, com suas capacidades inerentes de acomodar flexivelmente qualquer observação possível e, portanto, exibindo baixíssimo conteúdo de informação. Mas, muitas delas se aproximam das ciências “softs" (PIGLIUCCI, 2013), de modo que outros critérios demarcatórios têm sido explorados.

O assunto em questão é de extrema relevância, pois afeta diretamente à teoria de evolução, com a propagação de propostas desprovidas de observações confiáveis ou base racional. Após explorarmos o tema, partimos para uma análise anatômica da teoria evolutiva clarificando diversos conceitos evolutivos. Por fim, é encaminhada uma apreciação histórica da teoria evolutiva contemporânea, da fase inicial até sua versão atual estendida.

\section{DESENVOLVIMENTO}

\section{O problema da demarcação da ciência e as propostas prescritivas}

A incapacidade de avaliação popular quanto à confiabilidade de certas explicações para diferentes fenômenos tem contribuído para a propagação das pseudociências, um dos maiores motivos para a intervenção reparadora dos filósofos da ciência. 
O problema remonta à própria história da ciência moderna, com as primeiras tentativas de levantar peculiaridades que a justifique como forma confiável de obtenção de conhecimento. Confunde-se com a aquisição de identidade pela própria ciência (HULL e RUSE, 1998; STERELNY e GRIFFITHS,1999). Desde o tempo de Karl Popper, separar o "joio do trigo" tornou-se uma tarefa importante, de autoafirmação. Por um lado, há uma forma eficaz de domínio sobre a natureza, com predições testáveis e altíssima aplicabilidade e por outro, uma dita impostora, que usa jargão científico, mas é difusora de falsas verdades. 0 "canto da sereia" das pseudociências tem apego popular, e se mistura com a crença e superstição, constituindo placebo para muitas pessoas.

De acordo com o filósofo Imre Lakatos:

The demarcation between science and pseudoscience is not merely a problem of armchair philosophy: it is of vital social and political relevance. - Lakatos (1978, p.1)

Na demarcação entre ciência e não ciência, o problema começa com a abordagem dos diferentes tipos de ciências. Não formam um corpo de conhecimento homogêneo. Nas tentativas de categorização, diferentes status foram conferidos a elas. Há aquelas que gozam de status privilegiado, pelo rigor do método científico empregado, as chamadas "hards" (e.g., Física de partículas, Química, Biologia Molecular) e as que lutam para serem aceitas na 'mesa redonda' ("round-table" sensu ELDREDGE, 1995), as ditas "softs" (e.g., Psicologia, Sociologia e Economia). Entre as reprovadas pela baixíssima confiabilidade de resultados e falta de acúmulo de evidências favoráveis, estão as pseudociências [e.g., Astrologia, Criacionismo "científico" ("intelligent design") e Espiritismo "científico"].

Três critérios foram propostos como demarcadores do conhecimento científico (SOBER, 2008):

i) Verificabilidade, de Francis Bacon (1561-1626);

ii) Falsificabilidade, de Karl Popper (1902-1994);

iii) Vulnerabilidade, de Elliot Sober (1948-).

O raciocínio mais empregado nas ciências empíricas é o indutivo (=baconiano). Para Francis Bacon, seu principal proponente, a investigação científica começa com a libertação 
da mente (i.e., antecipatio mentis) de preconceitos (idola) ao iniciar as observações (CIVITA, 2000; MAGEE, 1998).

Nessa linha de raciocínio, um problema é detectado conduzindo ao encaminhamento de uma solução provisória (=hipótese). Com a qualidade e quantidade de evidências a favor da hipótese, tem-se (por indução) uma generalização a partir dos dados existentes. Verificando-se novas ocorrências, sustenta-se cada vez mais a generalização. Assim, a ciência progrediria pelo acúmulo de evidências novas às antigas, gerando um corpo de conhecimento perfeito e seguro da natureza.

Usando o método indutivo baconiano, muitas ciências lograram êxito. Adotaram seu critério de verificabilidade. Atualmente, a inferência estatística o tem como base. Quanto mais evidências se acumulam, mais próximo estaríamos da verdade. Assim, uma lei alcançaria o status de verdade.

A maior exigência do método baconiano está na possibilidade de verificação, tornando o enunciado de provável a conclusivo (i.e., verdade). Especificar quais condições objetivas usadas na verificação é algo fundamental para a eficácia do método.

Na verdade, cabe aqui assinalar que há enunciados verificáveis e conclusivos.

Eles podem ser:

(a) singulares ("Este animal é um mamífero e porta glândula mamária");

(b) existenciais (“alguns animais são mamíferos e portam glândulas mamárias”).

Porém, nem sempre a possibilidade de verificação é factível. Dependendo do contexto de época, as tecnologias necessárias podem estar indisponíveis ou insuficientes para confrontar o argumento. Para piorar, há os enunciados universais categóricos, do tipo "todos os cisnes são brancos", que abrangem casos reais (passados e presentes) e possíveis (futuros). E logo se depara com a impossibilidade de checar todas as ocorrências, tanto do passado e quanto do futuro. Por maior que seja a quantidade de evidências, não dá para assumir os enunciados como conclusivos. Em outras palavras, não dá para estabelecer uma generalização (OLIVA, 2012). 
Uma observação inicial isenta de preconceitos, como aquela defendida por Bacon, é algo ingênuo e utópico, já que ela está determinada por influências e experiências pregressas, a exemplo da problemática questão do livre-arbítrio (HAWKING e MLODINOW, 2010).

Karl Popper (1902-1994), filósofo austríaco do círculo de Viena, contribuiu com uma proposta prescritiva quanto à prática da investigação científica (POPPER, 1972; MAGEE,1974). Encaminhou um novo critério demarcatório para a ciência. Ao contrário de Bacon e filósofos positivistas, adotou uma falibilista ou negativista. Assim, surgiu o critério de falsificabilidade (Fig. 1).

Figura 1. Fluxograma do método hipotético-dedutivo de Karl Popper. O método consiste de duas etapas: (a) sintética, em que se formula a hipótese com base em problemas e observações; (b) analítica, na qual a hipótese é submetida a teste, podendo ser confirmada ou refutada.

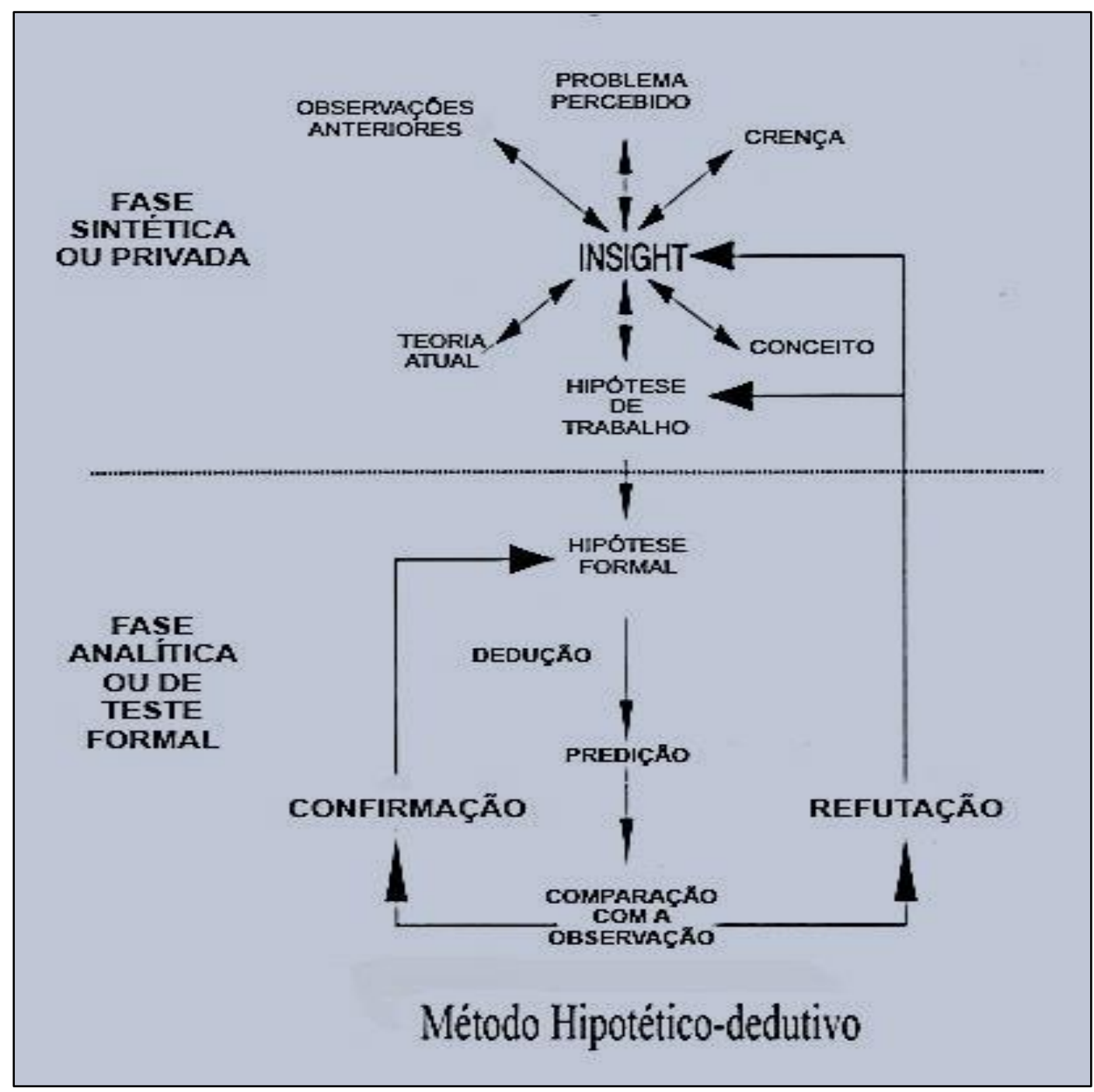

Fonte: Modificado de Peters (1989). 
Popper demonstrou que verificabilidade é um mito (POPPER, 1972; MAGEE, 1974; RUIZ e AYALA, 2000). Exatamente nesse aspecto, da impossibilidade de checar todas as ocorrências, que Popper constrói sua proposta prescritiva. Não é pelo fato de algo repetir que se pode dizer que necessariamente se repetirá, mesmo com todas as evidências favoráveis (NEIVA, 1998). Como exemplo, por demais explorado, cita que o fato do Sol ter nascido no horizonte todos os dias até então, não implica em dizer que nascerá amanhã. Há grande expectativa, alta probabilidade, mas não se pode afirmar que é uma verdade. Precisaríamos viajar no tempo, ir para o futuro, constatar o nascimento do Sol e voltar no tempo para comunicar a todos que "o sol nasceu amanhã”. Infelizmente, Mas ainda não temos uma máquina do tempo.

No método hipotético-dedutivo de Popper, a validade de uma conjectura científica se estabelece derivando suas consequências e avaliando se a predição derivada é ou não correta (POPPER, 1972; MAGEE, 1974). Para ele, ciência avança através da produção de conjecturas criativas e de tentativas arrojadas para refutá-las.

Uma vez que é impossível verificar integralmente um enunciado científico, só resta apontar se é falso, buscando exceções. A regra (modus tollens) é simples: uma generalização é falsa se um contraexemplo é identificado (OLIVA, 2012). Portanto, só é considerado enunciado científico aquele sujeito à refutação empírica pela identificação de contraexemplos. Ao contrário da verificabilidade, que, por definição, levaria à estagnação de conhecimento, a falsificabilidade conduz ao avanço, gerando novas situações que, em si, necessitam ser explicadas com novas hipóteses.

Pronto e bom. Mas há problemas também quanto à aplicação do critério de falsificabilidade nas ciências empíricas. Uma coisa é na teoria e outra, na prática. Deve-se separar "possibilidade lógica de refutação (=falsificação)" da "prova experimental prática e conclusiva de refutação". Por exemplo, desbancar o enunciado “todos os cisnes são brancos" é fácil, basta achar um cisne preto. O problema vem da refutação por experimento, uma vez que não é possível estabelecer de modo conclusivo que uma teoria é falsa. Os instrumentos de teste podem nem sempre ser fidedignos, a escolha do contraexemplo (e.g., evidência contrária) pode ter sido equivocada e os dados podem estar incorretos (CHALMERS, 1993). Tudo isso pode acarretar em:

i) Erro Tipo 1, acreditar em algo falso, ou seja, rejeitar uma hipótese quando ela é boa; 
ii) Erro Tipo 2, rejeitar algo verdadeiro, ou seja, aceitá-la quando ela não é.

Por isso, tão importante quanto à formulação da hipótese, é a escolha do protocolo de investigação capaz de melhor descrever certa observação.

Novas tentativas surgiram na busca do critério demarcador de ciência. O filósofo da ciência David Lee Hull (1935-2010) indicou que verificabilidade e falsificabilidade dependem dos enunciados (HULL, 1974, 1987). Distinguiu três tipos de enunciados:

i) Todos os A são B. Lei Universal (=enunciado categórico universal). É potencialmente refutável, mas não totalmente verificável. Há assimetria entre a evidência que confirma e aquela que refuta;

ii) Alguns A são B. Lei Universal (=enunciado existencial). Basta achar um exemplo e pode-se verificar. Mas, não dá para refutar;

iii) Alguns A são B em 1970. Universal Numérico. Pode-se confirmar ou refutar.

O filósofo Elliott Sober (1948-) argumenta que para uma hipótese ou teoria ser testada nos moldes de Popper, de forma estritamente dedutiva, deve-se assumir qualquer uma das premissas auxiliares e todas elas como verdadeiras. Caso contrário, não dá para testar dedutivamente. Nas ciências biológicas, particularmente aquelas ciências históricas, que lidam com indivíduos naturais, a situação se complica. Sendo assim, apontou uma saída: o critério de vulnerabilidade (SOBER, 1993, 2008, 2011).

Para Sober (2008), hipóteses científicas devem ser vulneráveis às observações. Para ser suportada por evidência, deve ser vulnerável à infirmação (i.e., uma nova combinação ou formalização que contradiga a anterior). A proposta pode ser resumida no seguinte esquema:

\section{$P(\mathrm{O} / \mathrm{H} 1)>P(\mathrm{O} / \mathrm{H} 2)$, então $P($ não-O/H1) $<P($ não-O$/ \mathrm{H} 2)$}

Ou seja, se uma observação (O) favorece uma hipótese (H1) sobre uma hipótese (H2), então a observação contrária favorecerá $\mathrm{H} 2$ sobre $\mathrm{H} 1$, porque a probabilidade de dado $\mathrm{H} 1$ é maior que a probabilidade de «não-O» dado H1 deve ser menor que a probabilidade de «não-O» dado H2.

Então, SOBER $(1993,2008,2011)$ concentra-se na probabilidade como uma ferramenta quando não se pode aplicar o critério da falsificabilidade. 
No entanto, cabe aqui uma crítica movida pelas ferramentas do ceticismo (SMITH, 2004). Em linhas gerais, o argumento cético pode ser resumido da seguinte forma: (1) eu não sei que não-H; (2) se eu sei que não-H, então eu não sei C; (3) logo, eu não sei que C. Ou seja, a ideia de justificação conduz a um impasse insolúvel!

Considere $\mathrm{P}$ e não-P justificadas por certa crença $\mathrm{Q}$ que tem uma descrença não-Q como antítese. Pode-se argumentar que aceita-se P (rejeitando não-P) considerando que Q é boa justificativa. Mas há um problema: por que afirmar $Q$ como verdade e não-Q? Aceita-se tendo em vista um argumento $\mathrm{R}$ como referência. Mas, a solução não termina aí. Surge outro problema. Por que se escolheu R em detrimento de não-R? Sendo assim, o processo segue em regressão infinita.

Mesmo fixando um ponto de parada, pelo acúmulo de evidências obtidas, portanto, autoevidente, a justificativa, também não é boa. Adota-se deliberadamente a crença em $Q$ como marco para justificação de Q e de P. Por que afirmar Q sem justificação? Alguém poderia sustentar não-Q alegando que é autoevidente e carece de justificação. Logo, a solução é arbitrária.

Buscando outro caminho, poder-se-á justificar Q a partir de $\mathrm{P}$, fugindo da regressão infinita e da arbitrariedade. Porém, justificar $P$ a partir de $Q, Q$ a partir de $R$ e $R$ a partir de $P$ gera raciocínio circular, ou seja, uma tautologia. P é assumido para justificar P. Não se pode assumir um ponto controverso para justificá-lo. E sem justificação, não há conhecimento científico. Então, uma visão mais refinada da objetividade quanto à realidade, além do sensocomum, faz-se necessária. Uma visão probabilística novamente poderia ser o caminho.

LAKATOS $(1978,1987)$ também criticou o critério de falsificabilidade de Popper e abordou de outra forma o avanço do conhecimento científico. Propôs uma metodologia para os programas de pesquisa ou de investigação científica. Argumentou que os cientistas não abandonam suas teorias ao se depararem com adversidades, como falsificação ou anomalias. Ao contrário, são bastante conservadores e criam explicações ad hoc até onde puderem! (CHALMERS, 1993; PIGLIUCCI, 2013). Essas hipóteses ad hoc são justificativas criadas para proteger uma hipótese do confronto e da provável refutação, ou seja, uma heresia dentro da investigação científica.

Para LAKATOS $(1978,1987)$ os programas de pesquisa podem ser divididos em "partes": 
i) Núcleo sólido - conjunto de conceitos ou ideias assumidas como verdadeiras;

ii) Cinturão protetor - conjunto de hipóteses auxiliares que protegem o núcleo;

iii) Cinturão (=valor) heurístico - capacidade de explicação diferencial.

Considere o enunciado que hoje é quarta-feira. Mas alguém assume, de forma equivocada, que hoje é sexta-feira e fim de papo. E isso faz parte do núcleo sólido. Mesmo com o núcleo sólido equivocado, há possibilidade de gerar boas hipóteses que conduzem a novas situações testáveis. Por exemplo, sexta-feira vem depois de quinta-feira e sexta-feira vem antes de sábado. Ou seja, as hipóteses auxiliares são válidas.

Mas como decidir se um programa de pesquisa é melhor que outro? Uma saída é apelar para o valor heurístico - um indicativo da capacidade diferencial de explicação. Considere a aplicação de uma prova de 10 questões para duas pessoas. A prova é a mesma. Uma delas consegue, das 10 questões, responder corretamente 8 e a segunda pessoa, 6. A primeira tem uma heurística positiva em relação à segunda. Sendo assim, num sistema de perguntas e respostas possui maior poder explicativo. Programas são ditos progressivos quando têm heurística superior aos rivais, que por sua vez são chamados de regressivos (com menor valor heurístico). Os progressivos conseguem explicar mais e encaminhar mais predições. Em suma: prever fatos novos é o que importa. E, como já dito (FIGUEIREDO e OLIVEIRA, in press), prever em ciência é simplesmente proibir que a alternativa ocorra simultaneamente. Para Imre Lakatos, é assim que a ciência avança (LAKATOS, 1978; 1987; GEWANDSZNAJDER, 1989, 2010).

Na história das ciências, há vários casos em que um programa de pesquisa científico engloba outro. Programas repletos de hipóteses ad hoc, tautologias ou conceitos metafísicos (i.e., intestáveis) embutidos estão condenados a travar ou estagnar o conhecimento científico, pois não conduzem a predições ou consequências testáveis. Tendem a ser regressivos.

A teoria evolutiva se enquadra na perspectiva de Lakatos como um programa de pesquisa científico progressivo, acumulando evidências favoráveis e fazendo várias predições testáveis (RUSE, 1982, 1995; FUTUYMA, 1995; RIDLEY, 1986, 1987, 2006; ELDREDGE, 2010). 


\section{Darwinismo e filosofia da ciência}

Sendo o corpo de conhecimento científico que busca explicar a história da biodiversidade no nosso planeta, evolução não está livre análise crítica (MACBETH, 1971; PATTERSON, 1978; FOREY, 1981; R. PETERS, 1989; E. PETERS, 1996; SOBER, 2008, 2011) da Filosofia da Ciência e de suas ferramentas.

Evolução biológica é um conjunto de processos que levaram (e levam) à diferenciação e transformação de linhagens de seres vivos ao longo da história da Terra (JABLONKA e LAMB, 2010). Inclui aspectos de diversos níveis de generalidade e organização (GOULD, 2002; MAYNARD SMITH e SZATHMÁRY, 1997, 2007). Assim, fala-se de evolução molecular, epigenética, flutuações na frequência gênica de populações, radiação adaptativa de táxons, triagem de espécies, eventos de extinção em massa, biologia filogenética etc. Enfim, é um metafenômeno multifacetado (GOULD, 2002; MAYR, 1998; 2001, 2006; RUSE, 1979, 1982; WARD, 1997; 2006).

Estudar evolução é estudar a própria história da vida na Terra. É estudar a origem das espécies (incluindo a nossa), seus atributos e as circunstâncias que nortearam as transformações. Significa recuperar padrões e desvendar processos subjacentes à diversidade dos seres vivos (JABLONKA e LAMB, 2010; WHEELER, 2012; WILEY e LIEBEMAN, 2011). É querer saber o que aconteceu nessa história para depois tentar saber como e por que.

Como já dito, do ponto de vista da Filosofia da Ciência, em comparação com as ciências "hard", impõe-se o dilema da historicidade: história é constituída de fatos únicos, algo indesejado na investigação científica (PATTERSON, 1978; MARTINEZ e BARAHONA, 1998). É realmente um problema? Se for, como lidar com isso?

De praxe, o trabalho do biólogo evolucionista de "tempo profundo" é comparável àquele de um detetive criminalista interessado na reconstituição de um fato pelas pistas deixadas (DAWKINS, 2001). É uma tática que envolve a combinação de uma perspectiva hermenêutica (FIGUEIREDO e OLIVEIRA, in press) com a avaliação de hipóteses múltiplas (CHAMBERLIN, 1897; CLELAND, 2001; PIGLIUCCI, 2013). Confrontando-se hipóteses alternativas prevalece àquela hipótese com maior poder de explicação.

$\mathrm{Na}$ busca por uma explicação científica para a história da biodiversidade na Terra, o primeiro protagonista que vem à mente é o naturalista britânico Charles Robert Darwin 
(1809-1882), autor de On the origin of species by means of natural selection, or the preservation of favoured races in the struggle for life, de 1859 (DARWIN, 2002). Sua proposta evolucionista é conhecida como darwinismo.

Juntando a habilidade de cientista com a de escritor, Darwin reuniu evidências tiradas de diferentes áreas das ciências naturais em prol de uma proposta revolucionária: a diversidade dos seres vivos é explicada por descendência com modificação (BOWLER, 1989; MAYR, 2001).

Darwin forneceu uma robusta teoria para explicações históricas, libertando a biologia do "cordão umbilical" da Teologia (BOWLER, 1989; MAYR, 1998; DAWKINS, 2007). Entre tantas implicações da teoria, o homem deixou de ser tratado como "a imagem e semelhança de Deus", uma entidade superior aos demais seres vivos, para ser reconhecido como uma espécie a mais de primata, com suas adaptações particulares, sujeita às ações do ambiente e passível de extinção.

Evolução biológica é, ao mesmo tempo, fato (pelo conjunto de evidências) e teoria (pela tentativa de explicação) (GOULD, 2002). Esse fenômeno começou ca. 3,8 bilhões de anos e está em andamento (MAYNARD SMITH e SZATHMÁRY, 1997, 2007; LANDIM e MOREIRA, 2009; JABLONKA e LAMB, 2010).

Diversas áreas das ciências biológicas e geológicas acumularam evidências desde o tempo de Darwin. 0 somatório delas convergiu numa explicação comum, dando estruturação a uma teoria de evolução contemporânea (Fig. 2), bastante plástica e resiliente (RUSE, 1982, 1995; DOBZHANSKY, 1973; ELDREDGE, 1985, 2010). 
Figura 2. Evolução como um fato e seu inter-relacionamento com ramos diversos das ciências biológicas. A evolução biológica é sustentada por evidências multifacetadas e interdisciplinares oriundas de diversas áreas das ciências naturais. Com seus métodos e resultados diversificados, a explicação para a história da biodiversidade converge numa unificada teoria de evolução. Se a prova direta de que a evolução ocorreu em larga escala temporal está a cargo do registro fóssil, todas as outras áreas contribuem com evidências complementares.

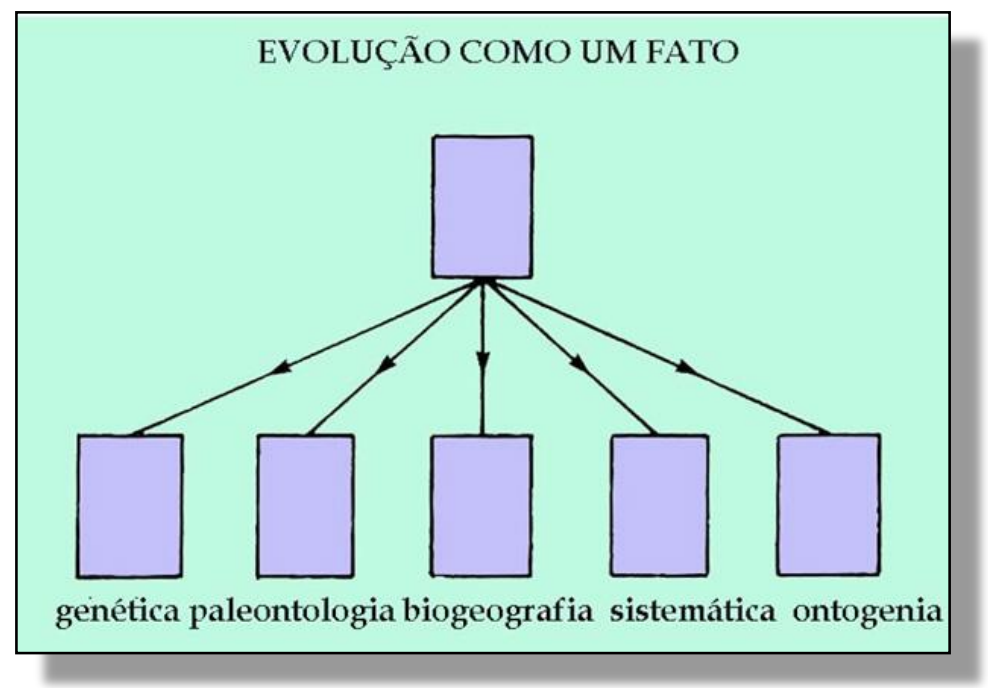

Fonte: Modificado de Ruse (1995).

A Biologia Evolutiva pode ser dividida em dois enfoques diversos, mas complementares (SOBER, 2008):

1. Padrão. Refere-se à estrutura geométrica gerada por descendência com modificação - a árvore filogenética (HEAMS et al., 2015). Trata-se de sistema hierárquico de grupos dentro de grupos detectado pelo compartilhamento de similaridades especiais em diferentes níveis de generalidade (NELSON e PLATNICK, 1981). Isso reflete a história de ancestralidade comum envolvendo todas as espécies de organismos (viventes e extintos) (WILEY e LIBERMAN, 2011) (Fig. 3). Ao contrário do que pensam os detratores da teoria evolutiva, mesmo lidando com fatos únicos, as condições que geram tais fatos são comparáveis e produzem padrões replicados acessíveis à investigação científica (e.g., convergências evolutivas moldadas por seleção natural). Sua reconstrução é legitimamente científica, com a escolha da melhor hipótese (com melhor valor heurístico) entre várias disponíveis, e o encaminhamento de deduções testáveis. Se não é possível aferir uma árvore filogenética, pode-se inferi-la. E primeiro passo na reconstrução do que aconteceu é a 
construção de cladogramas que correspondem à própria linguagem das ciências que lidam com relações históricas.

Figura 3. Árvore filogenética rascunhada por Darwin (1837) em um de seus cadernos, exibindo origem e divergência de espécies a partir de ancestral comum. Acredita-se que foi inspirada nas observações originais a partir da fauna de Galápagos. 0 padrão de relacionamento mostrado difere daquele defendido por Lamarck, que acreditava numa transformação linear e gradual das espécies associada ao aumento de complexidade. No esquema de Darwin, infere-se que as espécies compartilham diferentes ancestrais comuns em diversos instantes do tempo geológico. Os ramos com folhas (traço transversal na ponta) indicam aquelas espécies que alcançaram o atual horizonte de tempo; aqueles sem o traços são espécies extintas. Note que A, B, C e D descendem de uma espécie ancestral 1.0 padrão foi estendido como válido para retratar a história dos demais seres vivos.

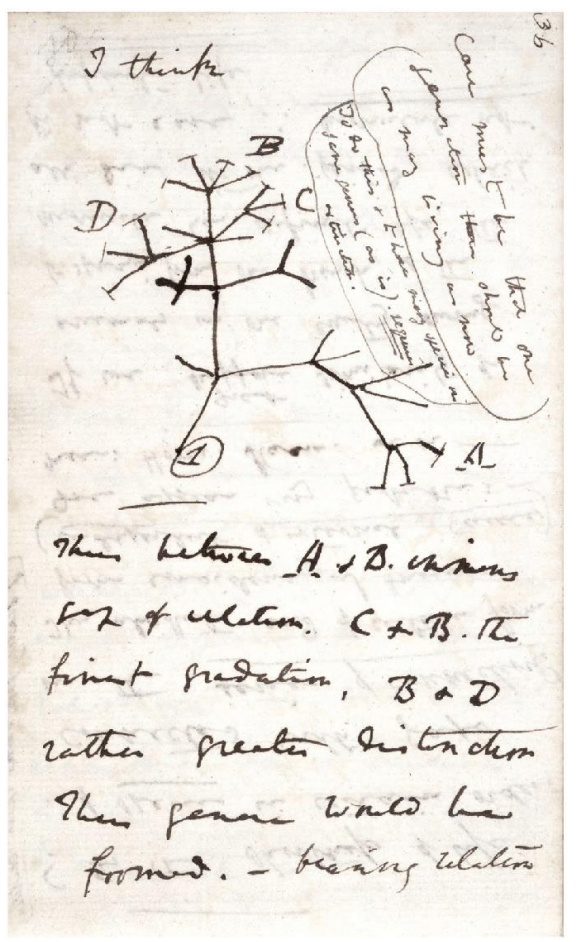

3. Fonte: https://commons.wikimedia.org/wiki/File:Darwin_tree.png

4. Processo. Darwin indicou a seleção natural como o principal processo evolutivo, aquele que molda e dissemina gradualmente as adaptações (RUSE, 1979, 1982). Constatou que, ao contrário da seleção artificial feita por criadores de animais, não há na natureza uma escolha premeditada e consciente dos aspectos que são de interesse em se fixar nos descendentes, nem uma meta (finalidade) a ser alcançada. A mudança evolutiva depende de problemas impostos pelo ambiente e da variabilidade genética de quem está interagindo com ele. Devese avaliar o quão eficaz é o atributo herdado para permitir sobrevivência e reprodução do 
organismo naquele ambiente. Ao contrário de Lamarck, Darwin não invocou qualquer lei subjacente que apregoasse a tendência herdada ("élan vital") na história das espécies para serem progressivamente mais complexas; tampouco apelou para uma lei de uso e desuso (MAYR, 1998). Também chamou a atenção para a realidade da extinção no tempo geológico. Além da seleção natural, Darwin indicou que outros mecanismos evolutivos: inércia filogenética (i.e., retenção de aspectos ancestrais e restrições físicas, baixa evolubilidade) e a correlação de caracteres (i.e., um traço favorecido por seleção pode estar associado a outros que são neutros ou até mesmo deletérios) (SOBER, 1984, 2009, 2011).

Em linhas gerais, o darwinismo está alicerçado nas seguintes constatações (MAYR, 2001, 2006):

(a) As espécies não surgiram "prontas" (i.e., imutáveis, fixas, permanentes). Elas variam no tempo e no espaço geográfico sofrendo mudanças herdáveis ao longo de gerações, por milhares ou milhões de anos, e são passíveis de extinção;

(b) Ancestralidade comum - a explicação para as similaridades compartilhadas entre as espécies está na existência de ancestrais em comum. Os aspectos ditos homólogos, aqueles herdados de ancestral, são indicadores e podem ser mantidos ou modificados ao longo de gerações (Fig. 3);

(c) Multiplicação das espécies (=especiação) - todas as espécies viventes e extintas exibem relações de parentesco, em menor ou maior grau, compondo a árvore filogenética, de estrutura normalmente ramificada (=cladogênese) e de coesão contínua (=anagênese). Espécies surgem somente de espécies ancestrais por isolamento e divergência devido a mudanças herdadas e acumuladas (WHITE, 1978; ENDLER, 1977; OTTE e ENDLER, 1989; FOREY, 1981; COYNE e ORR, 2004).

(d) Gradualismo - Inspirado na proposta de Charles Lyell para as explicações históricas em Geologia, Darwin introduziu na Biologia Histórica a ideia que a mudança adaptativa na história das linhagens evolutivas é um processo gradual, constante e acumulativo (SIMPSON, 1944, 1953).

(e) Seleção natural - é o principal mecanismo de evolução, aquele que produz as adaptações das espécies, ajustando-as aos problemas impostos pelo ambiente. Com o passar 
do tempo, num contínuo de transformações, mudanças espalhadas pela seleção natural nas populações de uma espécie ancestral se acumulariam a ponto de ocorrer gradualmente novas populações de espécies descendentes (WILLIAMS, 1966; ENDLER, 1986; SOBER, 1984, 1993).

Ainda, para se compreender melhor o darwinismo, dois conceitos merecem consideração: ancestralidade e linhagem.

Considere que os pais são os ancestrais imediatos de seus filhos na história genealógica familiar, uma relação de parentesco básica, que envolve duas gerações. Logo, para satisfazer essa relação, o grau de simililaridade genética deve ser maior entre pais e filhos do que para com outros indivíduos usados como controle.

No teste de paternidade da Biologia Forense faz-se a comparações entre sequências de DNA. A técnica usada mostra a semelhança nas sequências de bases nitrogenadas de amostras de DNA dos pais e do bebê. Nessa análise, o grau de confiança deve ser elevado para ser válido (99,99\%).

Em adição, no genoma humano, há regiões polimórficas em setores não codificantes que indicam marcantes diferenças individuais. Em conjunto, essas regiões representam o caráter único de uma pessoa. É a sua própria identidade. As regiões polimórficas são herdadas $50 \%$ do pai e $50 \%$ da mãe, o que permite identificar se um indivíduo é ou não progenitor de outro (CARROLL, 2006).

O protocolo utilizado na ciência forense pode ser estendido e incrementado para se inferir níveis de parentesco entre espécies de seres vivos em função da similaridade nas sequências de DNA. Dessa forma, recupera-se a relação de parentesco por ancestralidade comum.

O grau de similaridade tende a ser mais distante quanto mais distante for a linhagem. Mas, há genes que são bastante antigos e conservadores, e que foram reutilizados em linhagens mais recentes, num verdadeiro processo de "liga-e-desliga" gênico (CARROLL, 2006; 2011; JABLONKA e LAMB, 2011). Essas informações também corroboram a existência de uma única árvore filogenética.

Linhagem é uma sequência de indivíduos em posição ancestral-descendente, formando um contínuo coeso determinado por intercâmbio genético (WILEY, 1980, 1981; WILEY e 
LIEBERMAN, 2011). Entre os organismos assexuados, o padrão de relacionamento entre indivíduos é dicotômico, resultante de divisão binária. E clones são produzidos. Caso não apresentem mudanças de geração após geração, à princípio não padeceriam de descendência com modificação (PETERS, 1989). Um instante de violação da evolução. Mas isso não impede trocas horizontais de genes e também não implica em perda de identidade (DOOLITTLE, 1999; BLEIDORN, 2017) .

Entre organismos de reprodução sexuada, o padrão é reticulado, produzido com os filhos na interação sexual entre macho e fêmea. Logo, não forma hierarquia. As relações reprodutivas entre os indivíduos que compõem uma linhagem populacional são ditas tocogenéticas. E as relações de parentesco entre espécies diferentes são chamadas de filogenéticas.

As espécies são linhagens populacionais. Mas, por extensão, táxons superiores (e.g., Hominidae, Homo, Mammalia, Primates, Eukaryota) - coleções de espécies geneticamente relacionadas - são também linhagens evolutivas. Enfim, todos os táxons são, na verdade, linhagens evolutivas. E o somatório de todas as linhagens corresponde a uma única e abrangente linhagem, a que une todos as formas de vida que existem e ou existiram na Terra (WOESE, 1998).

Todas as espécies estão aparentadas em maior ou menor grau e posicionadas em diferentes níveis na árvore filogenética (Figs. 3, 4). Os galhos da árvore filogenética representam o desenvolvimento das espécies no tempo geológico, indicando durações e taxas de evolução. As folhas representam espécies que alcançaram o atual horizonte de tempo. Galhos sem folhas são espécies extintas, aqueles que não geraram descendentes. Os nós representam instantes em que a espécie ancestral deixa de existir ao gerar espécies descendentes ("morte no parto"). O princípio subjacente indica que todas as espécies são reunidas por descendência; é como afirmar que dois indivíduos são irmãos porque são filhos da mesma mãe e não porque são parecidos. 
Figura 4 - Árvore filogenética das espécies de Homininae.

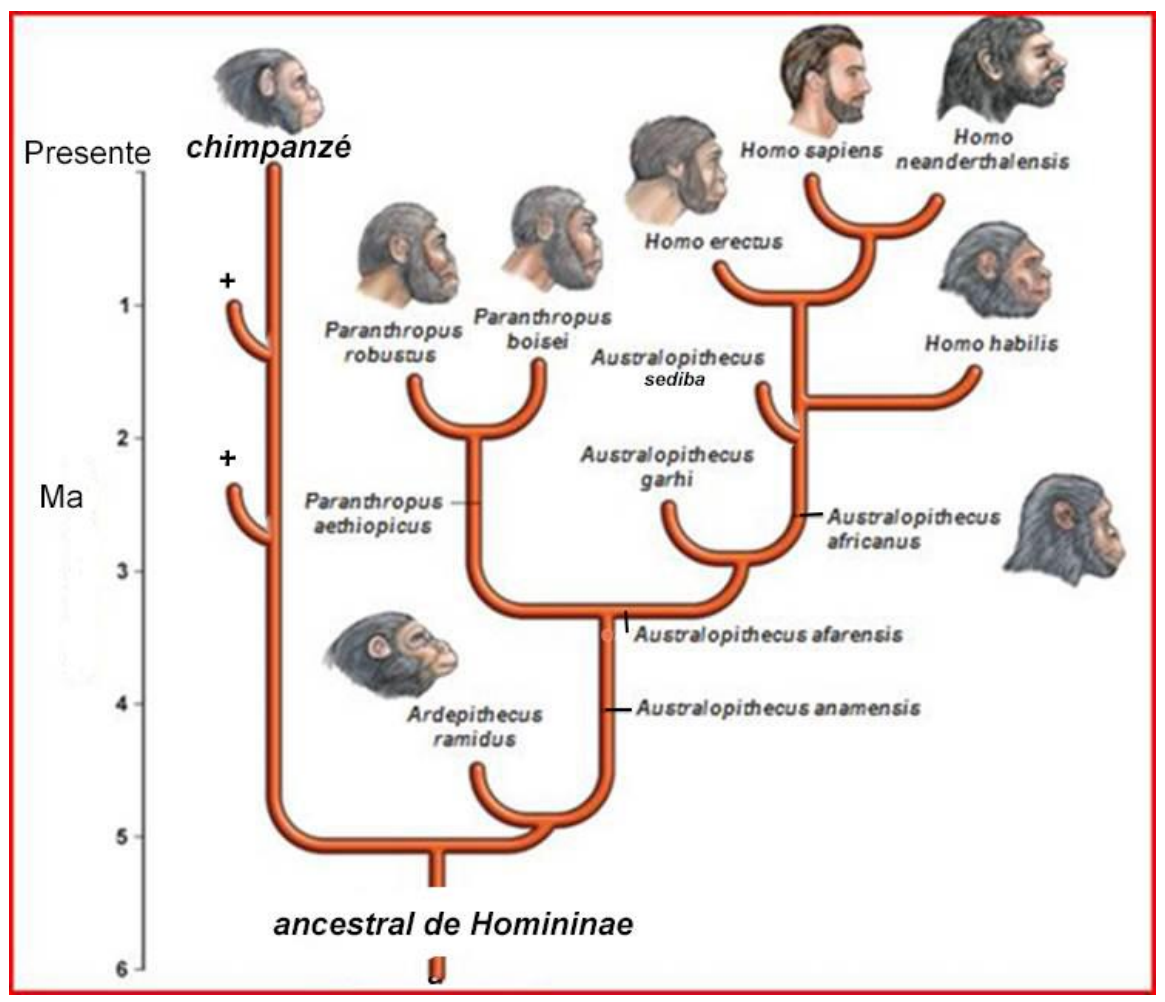

Fonte: Modificado de https://i.pinimg.com/originals/38/83/ae/3883ae59ddeba67b85aa1734fa58c233.jpg

Com base na leitura das árvores filogenéticas pode-se extrair várias deduções (implicações). Na figura 4, o chimpanzé (i.e., Pan troglotytes) representa o grupo-irmão da linhagem de Homininae (Ardepithecus, Australopithecus, Paranthropus e Homo). As cruzes dispostas ao longo da linhagem do chimpanzé indicam espécies extintas mais aparentadas com ele do que com as espécies do grupo-irmão Homininae. Logo, o chimpanzé é sobrevivente de sua própria linhagem. E, como toda e qualquer espécie de macaco vivente, o chimpanzé não é bom candidato para ser ancestral. Isso não quer dizer que não tivemos espécies ancestrais, ao nível bem remoto, com aspecto de macaco. É evidente que tivemos.

Por sua vez, Homo sapiens é também um sobrevivente de Homininae, já que as outras espécies do gênero estão extintas. Se "descermos" na árvore abaixo do ancestral comum de Homininae, notaríamos ancestrais com aspectos mais primitivos, evidentes nos gorilas e outros primatas basais. Logo, seriam macacos! Homo sapiens e Pan troglodytes, apesar de 
apresentarem taxas de evolução diferentes, são igualmente evoluídos, pois, mesmo com seus kits de adaptações próprios, alcançaram o mesmo horizonte de tempo.

No esquema apresentado, Australopithecus sediba é a espécie ancestral de todas as espécies de Homo. Se não tivesse existido, H. sapiens jamais existiria, uma vez que é um de seus descendentes. E, pode-se dizer que todos os gêneros e espécies de Homininae são tão humanos quanto Homo sapiens. E se grupos são reconhecidos por novidades evolutivas herdadas das espécies ancestrais e compartilhadas pelos seus descendentes, não faz sentido dizer que Homo erectus é mais intimamente relacionado com Homo habilis pelo compartilhamento de aspectos primitivos ("primitividades"). Por outro lado, observa-se que Homo neanderthalensis é grupo-irmão de H. sapiens. Sendo assim, deduz-se que a espécie ancestral mais recente que deu origem ao Homo sapiens era, sem dúvida, do gênero Homo. Logo, conclui-se que Homo sapiens não teria como ancestral imediato, um macaco, como diz a crença popular.

Mesmo cobrindo todos os seres vivos, a árvore da vida sobre a Terra exibe marcantes dissimilaridades. Na sua base, a estrutura não obedece a padrão dicotômico. Lá estão organismos unicelulares e assexuados. Reticulação, com troca de genes, parece ter sido a regra, mas há quem sustente que poderia ser até de estrutura anelar. O aparecimento de mitocôndria e cloroplasto, advogada pela corrente hipótese endossimbionte, são eventos marcantes nos primórdios da história dos eucariontes (WOESE, 1998; DOOLITTLE, 1999) que sustentam a hipótese de reticulação entre linhagens evolutivas primordiais. Com o surgimento de certos organismos eucariontes e do sexo, o padrão passou aquele visto nos tradicionais esquemas que ilustram a maioria dos livros de biologia, ou seja, dicotômico.

A árvore filogenética remonta a um ancestral comum que corresponderia a um conjunto de protorganismos que surgiu na Terra ca.3.8 Ga. Dele sabemos somente pelo que inferimos ter passado em termos de novidades evolutivas para seus descendentes: as sinapomorfias. Uma combinação de metabolismo, capacidade de multiplicação, variação e hereditariedade ilimitada garantiu o seu sucesso evolutivo desses protorganismos (MAYNARD SMITH e SZATHMÁRY, 1997, 2001). É o que chamamos de conotação ou intenção do conceito de vida. Esse primeiro ser vivo com estrutura celular até recebeu um apelido: LUCA - um acróstico para Last Universal Common Ancestor ou Last Universal Celular Ancestor (WOESE, 1998) (Fig. 5). 
A evolução defendida por Darwin praticamente conta como ocorrendo a partir de LUCA. A questão da origem da vida não faz parte de seu programa. De LUCA surgiram três linhagens evolutivas celulares ou grandes domínios da vida: Bacteria, Archaea e Eukaryota. Esses grandes clados incluem organismos dotados de membrana celular que sintetizam suas proteínas através de ribossomos. Estão embutidos na referência (=denotação) do conceito de vida.

Figura 5. Domínios da vida. Darwin introduziu a ideia de que todos os seres vivos extintos e viventes fazem parte de uma imensa árvore filogenética, ramificada e divergente. Nesse contexto, em passado recente, foram identificados três grandes linhagens evolutivas (=domínios): Bacteria, Archaea e Eukaryota. As duas primeiras contribuem com mais de 2/3 das formas de seres vivos em mais de $2 / 3$ da história da vida terrestre. $\mathrm{Na}$ perspectiva darwinista, seriam os organismos mais bem sucedidos, apesar do baixo nível de complexidade estrutural alcançado.

\section{Bacteria Archaea Eukaryota}

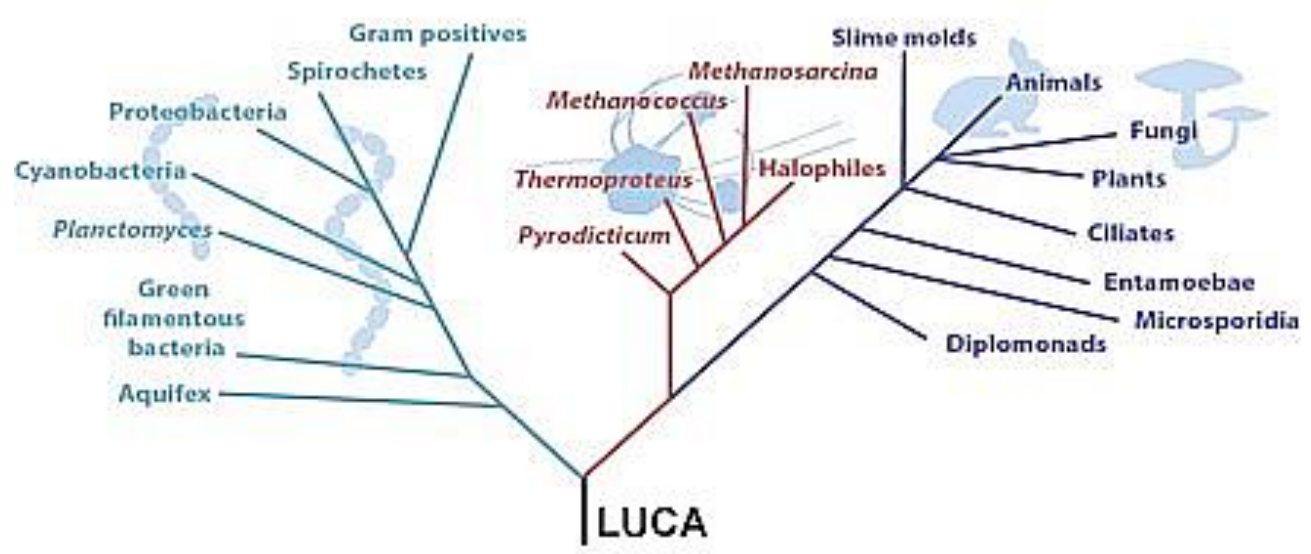

Fonte: https://bio.libretexts.org/@api/deki/files/12209/Tree-of-Life-v2-1024x566.png?revision=1

Paralelamente, na história dos domínios da vida sobre a Terra, surgiram os vírus, sem membranas, que atuam como parasitas ao nível genético. Eles codificam, pelo menos, um replicon (que permite multiplicação do genoma) e um capsídeo (i.e., uma estrutura complexa que protege, ajuda a penetrar no hospedeiro e permite entrada e saída de vírions ou produtos particulados da infecção). A importância dessa dicotomia é tão grande que vida poderia ser 
definida como: modo de existência de organismos que podem codificar proteínas através de ribossomos ou capsídeos.

$\mathrm{Na}$ atualidade, há várias técnicas para se recuperar a história de linhagens evolutivas em qualquer nível, seja populacional, específico ou supraespecífico. As espécies podem ser agrupadas em maior ou menor grau, a ponto de recuperarmos as sequências gênicas ancestrais (CARROLL, 2006). É o trabalho de áreas de ponta da biologia atual tais como filogeografia e filogenia molecular (AVISE, 2000; BLEIDORN, 2017).

De praxe, na recuperação da história por dados biomoleculares busca-se um indicador que permite a identificação de uma região específica do genoma de um organismo - o marcador genético molecular. Em geral, é uma sequência de DNA associada a um fenótipo. Nesse sentido, um gene pode ser um marcador quando está em posição fixa e invariável no genoma. Mas, aqueles passíveis de estudo podem ser poucos em espécies que não apresentam grande variabilidade e, portanto, um reduzido número de mutantes. Portanto, além de polimórfico, um bom marcador deve ser facilmente identificável e, de preferência, associado a um locus específico. Os marcadores podem ser: dominantes e não-dominantes. Os primeiros só permitem detecção de alelo dominante. Entre as técnicas correntes que usam este tipo de marcador, destacam-se: análise de proteínas totais, RFLP (Restriction Fragment Length Polymorphism) e DNA fingerprint. Entre aquelas que revelam marcadores não-dominantes estão a análise de isozimas e as que envolvem mini e microssatélites (OLIVEIRA, 2010).

Minissatélites são sequências de DNA moderadamente repetidas - mais curtas que a dos microssatélites -, de 10-100 pares de bases, arranjadas em cadeias de até 25.000 pares de bases. Normalmente estão concentradas nos cromossomos próximas do centrômero e formam grande parte da heterocromatina. 0 número de cadeias repetidas em sequências do satélite são hipervariáveis, mostrando grande variação entre indivíduos e acusando polimorfismo genético. Essas sequências repetidas dos minissatélites reveladas por sondas multilocais (i.e., pequenas moléculas de DNA radioativamente marcadas) constituem a base da técnica de identificação individual através de exame de DNA (i.e., DNA fingerprint). 0 comprimento preciso (i.e., quantidade de pares de bases) de um conjunto de arranjos ordenados de minissatélites no genoma é diagnóstico para cada indivíduo. A técnica introduzida por A.J. Jeffreys e colaboradores, na década de 1980 (e.g., JEFFREYS e MORTON, 1987). 
Microssatélite é cada um dos sítios do cromossomo que contém sequências muito curtas de DNA, entre 1- 10 pares de bases, repetidas várias vezes em determinado lócus (ALMEIDA et al., 2001; OLIVEIRA, 2010). Por isso, também são chamados de STR (Short Tandem Repeats) e SSR (Simple Sequence Repeats). Ocorrem ao longo dos cromossomos, mas são raros dentro de sequências que codificam proteínas. São utilizados como marcadores genéticos de alelos não-dominantes em estudos de variabilidade genética devido a alta taxa de mutação (e cobrindo muitos alelos na população) e facilmente analisados através de PCR (Polimerase Chain Reaction), bastando pequenas quantidades de DNA. Os microssatélites estão envolvidos na organização da cromatina e regulação da atividade dos genes. Atualmente, são muito utilizados na investigação de padrões de fluxo gênico, análise de parentesco e mapeamento genômico.

Entre as técnicas mais usadas no rastreamento de relações de parentesco entre espécies, destaca-se a do DNA mitocondrial (mtDNA) (Fig.6). Em contraste como o DNA nuclear (nDNA), que é herdado indistintamente dos ancestrais, o mtDNA, circular e pequeno (14-20 kb), é transmitido somente pela mãe. A taxa de substituição de nucleotídeos indicador de taxa de evolução - é 5-10 vezes superior ao DNA nuclear. Uma região conhecida por região controle ou alça $D$ é a mais vulnerável à substituição de nucleotídeos, acusando rápida taxa de mutação. Devido à alta taxa de evolução e ao compartilhamento de substituições entre sequências, a técnica é aplicada na reconstrução de relações filogenéticas de linhagens mais recentes (FERRAGUTI e CASTELLACCI, 2011). Sua aplicação na investigação da história da humanidade revelou uma "Eva" mitocondrial africana, que viveu a ca. 200.000 anos (SYKES, 2003). 
Figura 6. O mtDNA e a reconstrução de relação de parentesco. Esquema de reconstrução da história de linhagens de parentesco através do DNA nuclear e mitocondrial. Métodos moleculares têm sido encaminhados tendo me vista dois objetivos principais: (a) descrever a estrutura genética de populações atuais e (b) recuperar a história dessas populações, contextualizando fatores demográficos e ecológicos. Para tanto, mtDNA, pelo fato de sofrer rápida taxa de evolução e apresentar modo não recombinante de transmissão assexuada através de linhagens femininas, tem sido bastante utilizado.

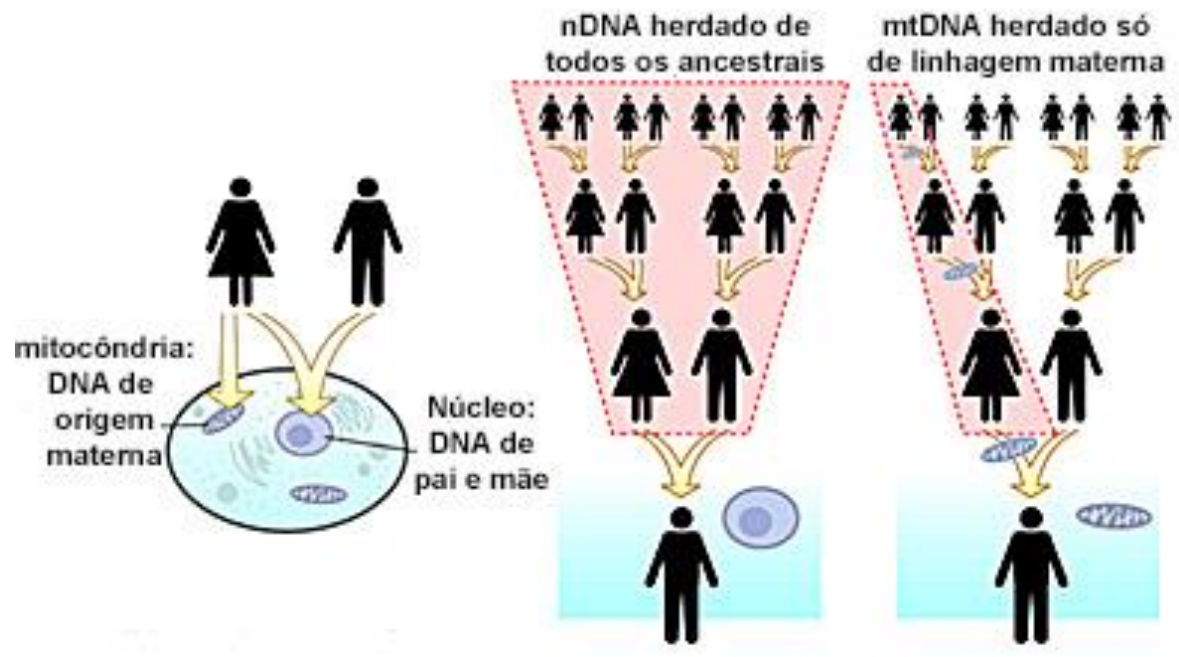

Fonte: Modificado de Museum of Paleontology's Understanding Evolution, 2019.

Por fim, os ribossomos formam um complexo RNA-proteína (i.e., ribonucleoproteína) produzido no nucléolo celular. Nessa organela ocorre a síntese de proteínas. Nos eucariontes, o seu conjunto (80S) é subdividido em subunidades $60 \mathrm{~S}$ e 40S. A última contém o $18 \mathrm{~S}$ rRNA e cerca de 30 proteínas diferentes. Pelo fato de ser comum a todos os organismos celulares, aparecer em grande quantidade e ser facilmente isolado e sequenciado, ter natureza conservadora por longo tempo geológico, conteúdo de informação alto, o rRNA tem sido bastante utilizado nas reconstruções filogenéticas de linhagens muito antigas (RAF, 1988).

\section{Seleção natural e adaptação: o coração do darwinismo}

A resposta dos organismos aos problemas ambientais é a adaptação por seleção natural. Isso explica o fino ajuste gradual em forma e função (WILLAMS, 1966). 
Para Darwin (2002) a seleção natural tem como unidade de atuação o organismo individual, compondo uma linhagem evolutiva (LÁZARO, 2000). Com isso, os efeitos da seleção podem ser verificados geração após geração, pois são herdáveis. Nas palavras dele: “ao princípio, graças ao qual cada pequena variação, se útil, se conserva, dei o nome de seleção natural".

Cabe ressaltar que sobrevivência e reprodução possuem prioridades diferentes. A primeira é pré-requisito da segunda. Uma superestimativa da segunda levou a um reducionismo no evolucionismo contemporâneo. E, por outro lado, manter-se é menos arriscado que mudar. As espécies tendem a ser conservadoras, de modo que homeostase predomina e a variabilidade com seu repertório (i.e., plasticidade fenotípica) é utilizada nos momentos de crise ou instabilidade ambiental (JABLONKA e LAMB, 2010).

Dawkins $(1976,2006)$ argumenta que seleção natural teria o status de lei científica dentro das ciências biológicas. Indicou que a sua unidade de atuação seriam os genes, distinguindo replicadores ("genótipo") de veículos ("fenótipos"). Alelos competiriam entre si pela descendência. A proposta gerou muita discussão, sua postura revelou-se ultradarwinista e reducionista, ignorando outros mecanismos evolutivos.

Por outro lado, Lewontin (2002) afirma que o reconhecimento de leis dentro da variação não reforça esse determinismo. O fato de haver problemas na distinção entre causa e efeito como se vê na natureza, entra em choque com a proposta de Dawkins (1976). O aumento da quantidade de indivíduos numa população pode ocorrer independentemente do aparecimento de aspectos identificáveis como vantajosos em termos competitivos.

Para Ruse $(1979,1982)$, a seleção natural se apresenta de forma indeterminada, resultante da atuação de leis probabilísticas, algo característico dos fenômenos biológicos.

Mayr (2001, 2005, 2006) afirma que na natureza é possível observar muitos aspectos de regularidades, porém não são universais, reiterando que são probabilísticas e muito restritas no espaço e no tempo.

Darwin demonstrou que cada espécie possui potencial para produzir grande número de descendentes a cada geração (RUSE, 1982; BOWLER, 1989). No entanto, somente poucos conseguem sobreviver a ponto de contribuir para a sua perpetuação. 
A diferença na taxa de sobrevivência entre indivíduos que competem pelos mesmos recursos estaria condicionada às adaptações. Os favorecidos pela seleção natural teriam o potencial para produzir mais descendentes, escapar dos predadores, utilizar de forma mais eficaz certos recursos, contribuindo assim para a perpetuação, manutenção e disseminação de indivíduos do seu tipo dentro da espécie.

Adaptação no contexto evolutivo é diferente daquele do fisiologista quando lida com um indivíduo no seu tempo de vida (MEYER e EL-HANI, 2005). Não é um simples ajuste morfofisiológico dele a uma condição ambiental, tal como acontece com jogadores da seleção brasileira de futebol ao encararem a altitude de La Paz uma semana antes de um jogo decisivo ou com os peixes comprados numa feira livre no saquinho e que são colocados aos poucos no aquário até se "aclimatarem". Será no sentido evolutivo para a população nativa de La Paz e de outros lugares de altitude elevada, se for aspecto herdado, disseminado e mantido na população através de gerações pela ação da seleção natural. São variações que fornecem vantagens a seus detentores em relação a outros que não as possuem.

A duração da adaptação no tempo geológico vai depender do fato do ambiente sofrer poucas mudanças. $\mathrm{O}$ organismo que foi moldado para usufruir de certos recursos ambientais em certo tempo e circunstâncias pode não estar bem adaptado para novas condições. Adaptação é circunstancial. Portanto, quando se fala de adaptação, deve se ter em mente: adaptado em que sentido? Em qual ambiente?

Darwin defendia adaptação no sentido oposto àquele vigente na Inglaterra vitoriana, como produto perfeito produzido por mudança progressiva direcionada (BOWLER,1989). Essa perfeição não existe. É um artefato derivado da ideia de propósito (=teleologia) atribuído à natureza. E, pelo fato do ambiente mudar, torna-se falso o argumento criacionista que as adaptações são perfeitas e divinamente impostas. A ideia de propósito não faz qualquer sentido em evolução porque o ambiente não é permanente. Nenhuma solução moldada por seleção natural poderia ser considerada definitiva.

Em síntese, para Darwin, a mudança adaptativa moldada por seleção natural deveria ser gradual e constante, operando por várias gerações (MAYR, 1970, 1982, 2001, 2006; MAYR e PROVINE, 1982). A frequência acumulada dessas pequenas, numerosas e sucessivas modificações levaria ao surgimento de níveis diferentes de organização estrutural e 
taxonômica entre os seres vivos e conduziria a própria especiação (COYNE e ORR, 2004; COYNE, 2014).

Quando se fala de adaptação, um exemplo bastante utilizado em livros didáticos é aquele das lebres do Ártico (e.g., FUTUYMA,1993; SOBER,1984; HARVEY e PAGEL, 1993). Há lebres com pelagem parda e branca. As brancas tornam-se praticamente invisíveis à ação de predadores, já que se camuflam com facilidade na alva paisagem de fundo. Possuem maior chance de sobrevivência quando comparadas com aquelas de pelagem parda. Portanto, esse traço fenotípico favorável tende a se espalhar entre seus descendentes. Gera-se uma expectativa. A quantidade de lebres brancas tende a aumentar através das gerações, enquanto que a de pardas tende a diminuir. Não se trata de um fenômeno ao acaso, já que se pode fazer uma projeção (e.g., simulação) quanto ao aumento gradual de um tipo sobre outro na população.

Para que uma espécie sobreviva é necessário que um número suficiente de indivíduos também sobreviva a ponto de garantir a produção de descendentes. Essa probabilidade de produzir descendentes - uma medida do potencial reprodutivo - é o próprio sucesso evolutivo (=fitness) e os fatores ambientais que atuam sobre ele, a pressão seletiva (BEGOSSI, 1993).

$\mathrm{Na}$ Inglaterra vitoriana (1819-1901), a disputa entre indivíduos por recursos era conhecida como "luta pela sobrevivência”. Ainda hoje é explorada pela mídia, que dá ênfase ao aspecto cruel das relações entre predador-presa no cenário das savanas africanas, num verdadeiro reality-show (SMITH e SULLIVAN, 2008). Dessa forma, seleção natural aparenta ser sempre um aspecto negativo, eliminatório. Mas, por outro lado, a natureza é bastante complexa e interessante para ser reduzida a esse lugar-comum.

Atualmente, usa-se o termo competição sentido lato, em substituição à "luta pela sobrevivência", cobrindo diferentes aspectos ecológicos e evolutivos. Assim, se fala de competições interespecífica e intraespecífica. A seleção natural não só tem participação efetiva na eliminação de aspectos desvantajosos, como também contribui positivamente na modelagem de novos desenhos estruturais a partir de variabilidade preexistente (DAWKINS, 2006). Mudanças adaptativas fixadas se somam a outras ao longo de gerações. Esse papel positivo ou construtivo da seleção natural foi percebido originalmente por Darwin (BEGOSSI, 1993). 
A suscetibilidade de uma estrutura à ação modeladora da seleção natural é a sua evolubilidade - uma medida da capacidade de gerar novas propriedades (FERRAGUTI e CASTELLACCI, 2011; PIGLIUCCI e BAUDRY, 2013). Mas nem sempre uma estrutura é "enxergada" pela seleção natural, deixando-a intacta e acumulativa, como nos casos de influência ancestral.

Tabela 1 - Divisão do darwinismo em dois argumentos.

\author{
Argumento para a luta pela sobrevivência \\ Princípios verificados empiricamente: \\ (PI) Principio da Reproduçáo Organismos crescem ese multiplicam \\ gerando descendentes para a próximageraçằo. Há potencial para a \\ produçăo de muitos descendentes: Populaçóes săo capazes de aumentar \\ em número exponencialmente $1 \vdash 2 \vdash 4 \ldots$ Mas logo nota-se um frèo $\ldots$ \\ Muitos nâ sobrevivem para contribuir para a reproduçăo. \\ (P2) Principio de Dependéncia todos os organismos dependem de \\ recursosnaturais. \\ Observações factuais: \\ (FI) Hấ uma quantidade limitada de ambientes em que há recursos \\ naturais. \\ (F2) A disponibilidade dos recursos nos ambientes varia no tempo. \\ (F3) Há variaçấo identíficável na forma e no comportamento dos \\ organísmos. \\ Conclusṍes de Darwin: \\ (c) Deve haver competiçăo ou "luta pela sobrevivência entre \\ organismos por recursos naturais. \\ (O) "Luta pela sobrevivểncia" euma evidência para explicar padrö́es de \\ abundância e variaçăo entre organismos.
}

\title{
Argumento para a seleção natural
}

Princípios verificados empiricamente:

(PI) Alguns aspectos habilitam organismos a utilizar mais recursos que aqueles que não os possuem.

(P2) Organismos produzem descendentes similares que tendem a ser mais similares aos progenitores (=ancestrais), mas há variaçóes considerăveis nos membros da populaçáo.

(P3) Organismos com aspectos vantajosos tenderằo a ter maior sobrevivência e produzir maior número de descendentes (sucesso reprodutivo) que seus rivais:

\section{Observaçốes factuais:}

(F1) Háluta pela sobrevivếncia na natureza:

(F2) Umagrande quantidade de variaçóes que ocorre nos diferentes. aspectos dos organismos.

(F3) Alguns aspectos podem ser vantajosos, neutros, ou desvantajosos nautilizacăo dos limitados recursos naturais.

Conclusẫo deduzida de príncípios e fatos:

(C) Seleçao natural ocorre entre os organismos de modo a favorecer o aumento do número de organismos com aspectos vantajosos em relaçăo aqueles que năo os possuem.

Fonte: Caplan, 1987. 
Apesar da aceitação do fato da evolução pela maioria dos cientistas contemporâneos, alguns autores atacaram o processo de seleção natural acusando-o de tautologia (MACBETH, 1974; PATTERSON, 1978; HERMANN, 2012). Cabe uma resposta. Considere o enunciado: seleção natural implica em sobrevivência diferencial. Alguns indivíduos sobrevivem e, portanto, deixam mais descendentes que outros que não se acasalaram ou cujos descendentes pereceram nas fases iniciais da vida. O mais apto é aquele que sobrevive. Se seleção natural for definida como a sobrevivência do mais apto, então pode ser transcrita sob a forma de circunlóquio. Quem é o mais apto? É aquele que sobrevive. Logo, seleção natural seria: a sobrevivência dos que sobrevivem. Seria uma tautologia - uma forma de dizer a mesma coisa com outras palavras, nenhuma consequência é extraída (PETERS,1989). Nada de predição. Só através da sobrevivência e consequente geração de descendentes há razões para se afirmar que um organismo estaria melhor adaptado que outro. Mas, um aumento na fecundidade pode não estar associado com o surgimento de alguma variação de fornece vantagens (LEWONTIN, 1979). Logo, a seleção natural seria desprovida de qualquer conteúdo empírico. Certos entusiastas darwinistas, como o sociólogo e filósofo Herbert Spencer (1820-1903) utilizaram o enunciado tautológico - sobrevivência do mais apto -, em muitos livros. E o próprio Darwin o endossou (EISELEY, 1958).

Porém, a teoria não é tautológica da forma com que Darwin a apresentou originalmente: "Devido à luta pela vida, qualquer variação, seja leve ou de qualquer procedência, se for de qualquer forma favorável a um indivíduo de qualquer espécie, em suas relações infinitamente complexas com outros seres orgânicos e com a natureza externa, levarão à preservação daquele indivíduo, e serão herdadas por seus descendentes. A prole, dessa forma, terá uma melhor chance de sobrevivência, uma vez que, dos muitos indivíduos de qualquer espécie que periodicamente nascem somente um reduzido número sobrevive. Eu chamei este princípio, pelo qual cada leve variação, se útil, é preservada, pelo termo seleção natural (...)".

Analisando o problema, Caplan (1987), apontou que o Darwinismo pode ser dividido em dois argumentos maiores, mas complementares (Tabela 1).

Com já dito, além da seleção natural, outros processos evolutivos ocorrem. 0 próprio Darwin estava ciente disso (SOBER, 2010). Atualmente, podem ser identificados como (SOBER, 2008, 2010): 
(a) Inércia ou influência ancestral - a retenção de aspectos ancestrais (i.e., plesiomorfias) que apresentam baixa ou nula evolubilidade (e.g., estruturas vestigiais);

(b) correlação de caracteres - no caso de aspecto neutro ou deletério se apoiar ("pegando carona") naquele que está sendo moldado pela seleção natural.

Figura 7. Frentes de estudo do evolucionismo contemporâneo. O núcleo central do darwinismo inclui variabilidade genética, hereditariedade, seleção natural e adaptação. Esses elementos foram usados até a década 1970 para explicar praticamente tudo na teoria evolutiva tendo como referências os resultados da genética de populações. Competição entre indivíduos adultos para ver quem deixaria mais descendentes na próxima geração era considerada a razão de ser da existência das espécies.

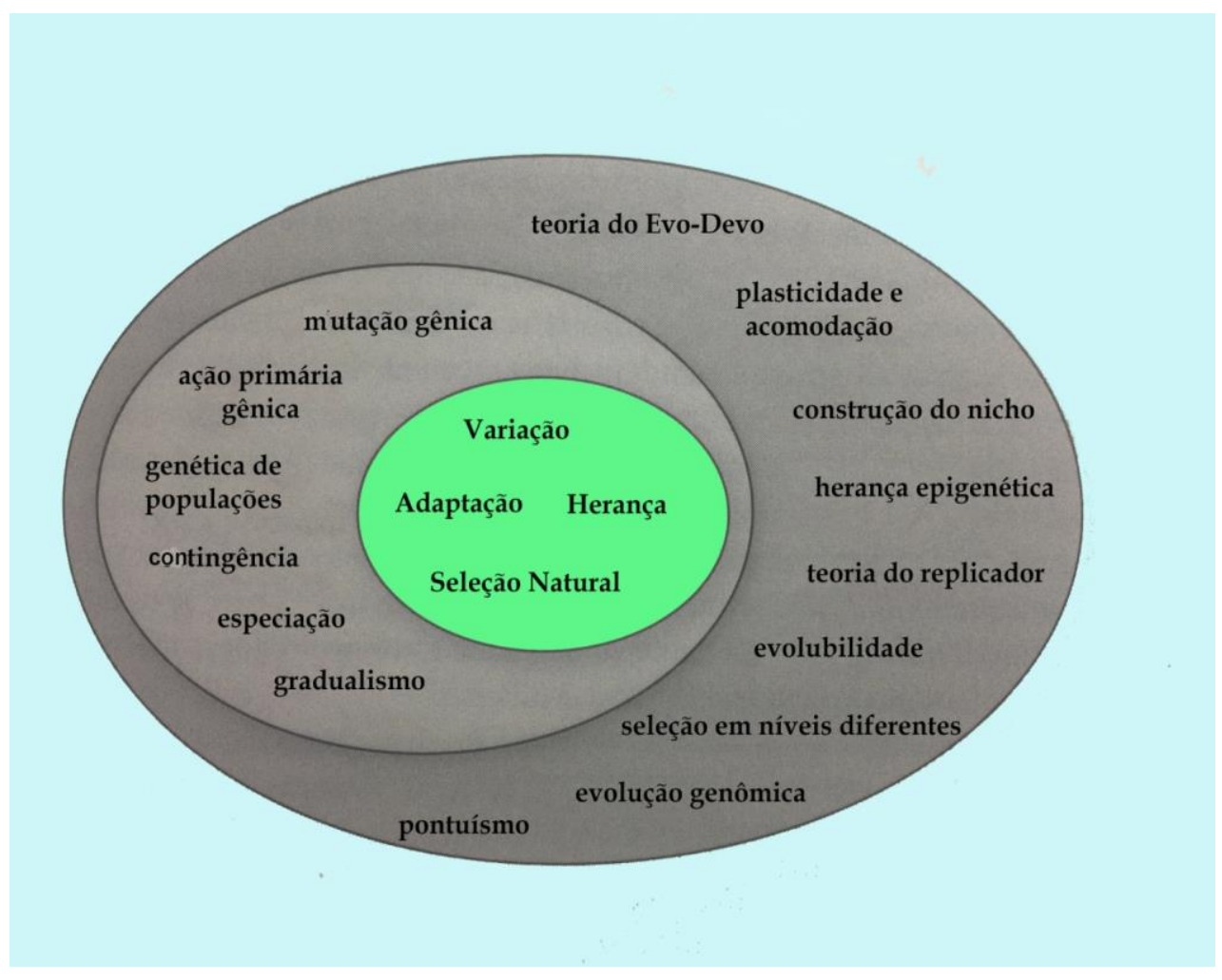

Fonte: Modificado de Pigliucci e Baudry (2013). 


\section{Evolucionismo moderno e a síntese estendida}

NELSON (1970) indicou que a Biologia poderia ser dividida em dois grandes enfoquess: (a) Biologia Geral (=nomotética) e (b) Biologia Comparada (=histórica).

Na Biologia Geral a ênfase está na descrição e investigação de processos ou mecanismos segundo um protocolo indutivista (=baconiano). o padrão depende do processo ou modelo assumido. Escolhe-se algum organismo de interesse a partir do qual problemas são detecatados e hipóteses são encaminhadas. Por fim, um enunciado geral é feito. Nessa perspectiva, a diversidade torna-se um obstáculo, já que o programa de investigação se concentra em propriedades indicadoras de uniformidade.

Na Biologia Comparada, o enfoque está centrado na explicação da diversidade revelada ao se comparar propriedades em organismos diferentes. O objetivo principal é recuperar padrões para tentar explicá-los. Isso remete a causas históricas. A princípio, o método hipotético-dedutivo de Popper foi endossado com sendo o melhor caminho. Entre os pilares da Biologia Comparada tem-se: Sistemática Biológica e Biogeografia (NELSON e PLATNICK, 1981). A primeira lida com as classificações produzidas em função das relações das espécies no tempo geológico. A segunda lida com a história da distribuição geográfica das espécies.

Na Biologia Comparada, Sistemática Biológica está associada a uma perspectiva evolucionista, que lhe dá justificativa (RIDLEY,1986). E nela reside também três grandes conceitos controversos interligados (RIEPPEL, 1988): Holismo versus Reducionismo; Forma versus Função; Hierarquia (classes dentro de classes) versus Continuidade. Essas diferentes visões confrontam-se desde o início do evolucionismo e até mesmo, bem antes desse.

A Teoria Sintética de Evolução ou Neosíntese é a frente atual do evolucionismo (ELDREDGE, 1985; RIDLEY, 2006) (Fig. 7) - o "upgrade" do darwinismo. Foi construída como uma resposta às propostas de evolução baseada num só fator (e.g., mutacionismo, geoffroyismo). Teve início na década de 1930, sob o comando de geneticistas e ecólogos de populações, como uma visão unificadora e multifacetada da evolução. Logo incorporou novas perspectivas, particularmente as oriundas da biologia molecular, cladística, biologia do desenvolvimento, paleontologia e biogeografia (OLSON e BRUNK, 1986). A Neosíntese é caracterizada por: 
(a) Ênfase na microevolução (genética e ecologia de populações) - Com o "casamento" do mendelismo ao darwinismo e a refutação do mutacionismo, evolução basicamente se concentrou na ação primária gênica e na frequência de alelos nas populações ao longo de gerações. $\mathrm{Na}$ essência darwinista da Neossíntese, evolução era explicada a contento por: variabilidade genética $\rightarrow$ seleção natural $\rightarrow$ competição $\rightarrow$ sucesso reprodutivo $\rightarrow$ adaptação (STEBBINS, 1974; SHEPPARD, 1975; OLSON e BRUNK, 1986). Na década de 1950, com a descoberta da estrutura e função do DNA, e consequentemente, emergência da biologia molecular, os genes tornaram-se o centro das atenções (WATSON e CRICK, 1953; WATSON, 1968). Aos poucos, isso levou a um reducionismo ainda maior. Na prática, os aspectos macroevolutivos foram relegados a segundo plano, rotulados de não-científicos (i.e., intestáveis) pelos microevolucionistas doutrinados pela filosofia das ciências "hard". A macroevolução era explicada de forma indutivista como acúmulo de mudanças microevolutivas. Assim, pela possibilidade de observação direta e experimentação, geneticistas tomaram as rédeas da investigação científica, e suas conclusões foram extrapoladas para vários níveis de organização. O caso mais extremo seja o do ultradarwinismo de Richard Dawkins com sua teoria do replicador (gene egoísta; vide DAWKINS,1976). Na década de 1980, uma perspectiva começou a ganhar aceitação com as descobertas de geneticistas interessados na base genética da mudança morfológica (i.e., EVO-DEVO e Epigenética). A incólume genética de populações, centrada nas flutuações na frequência de alelos em populações e no "adultocentrismo", teve que dar espaço para o "liga-desliga" da genética do desenvolvimento e ao "pedocentrismo" (ênfase em etapas ontogenéticas antecedentes das formas adultas). Aos poucos, outros mecanismos de herança além do DNA foram descobertos e o foco das atenções passou a ser a interface fenótipo-ambiente e não mais os genes em si (JABLONKA e LAMB, 2010).

(b) Conceito biológico de espécie. - Devido ao comando da genética de populações em questões evolutivas, um conceito de espécie que melhor se acomodasse ao objeto de estudo foi prontamente formulado e aceito (vide FIGUEIREDO e OLIVEIRA, in press). 0 eleito foi aquele de Ernst Mayr. Mas logo este se revelou pouco operacional e de pouca valia para evolução no tempo geológico. Em seu socorro, George Gaylord Simpson, (vide SIMPSON, 1971), introduziu o conceito evolutivo, englobando o de Mayr, dando-lhe temporalidade. Porém, dentro do contexto da reforma cladística, ROSEN (1979) demonstrou que a compatibilidade reprodutiva é aspecto primitivo (i.e., plesiomórfico), podendo ser retido na espécie descendente durante 
o processo de especiação. Mas isso não afetou a aceitação por parte de geneticistas de populações, que continuaram a considerar especiação como um processo gradual de aquisição de isolamento reprodutivo, incorporando conceitos correlatos obscuros, tais como superespécie, semiespécie e subespécie (MAYR, 1970; ENDLER, 1977). Aos poucos, o isolamento reprodutivo do conceito biológico (=reprodutivo) passou a ser substituído pelo conceito de coesão reprodutiva, numa combinação eficiente de explicações ad hoc (cf. QUEIROZ e DONOGHUE, 1990; QUEIROZ, 2007). Com o estreitamento de metodologias moleculares conectando genética de populações com sistemática e biogeografia (e.g., AVISE, 2000) o resiliente conceito de Mayr foi readaptado a ponto do conceito de subespécie ser também reavaliado (e.g., MULCAHY, 2008). No entanto, as críticas continuam (e.g., NELSON, 1989; NELSON e LADIGES, 2009).

(c) Gradualismo filético. - A visão darwinista tradicional para a história das linhagens é a de mudança adaptativa gradual sob a ação modeladora da seleção natural (STANLEY, 1979; TASSY, 1991). Assim, microevolução e macroevolução seriam dois extremos de um contínuo. A segunda deriva do acumulo de novidades evolutivas desde o nível populacional. Portanto, evolução como um todo, poderia ser explicada por extrapolação de processos detectados ao nível genético e populacional. Não obstante, o enfoque foi questionado no inicio da década de 1970, quando os paleontólogos Stephen G. Gould e Niles Eldredge introduziram o modelo do equilíbrio Pontuado (=pontuísmo) como alternativa para o padrão gradualista no "tempo profundo" (Fig. 8). Notaram que as espécies podem ser conservadoras ao longo de suas histórias, mantendo-se praticamente inalteradas após períodos curtos e tormentosos de cladogênese. Especiação revelou ser um processo não necessariamente ligado à ação gradual da seleção natural. Fatores estocásticos podem estar envolvidos de forma que a velocidade da mudança ambiental associada à especiação pode ser maior que a da mudança genética nas populações. Ao invés de corroborar o mecanismo simétrico de especiação alopátrica tradicional (dicopátrica), apontaram que as mudanças significativas ocorreriam em isolados periféricos, com predomínio de deriva genética e macromutações, de modo que o modelo de especiação peripátrica (i.e., em pequenas populações isoladas na periferia da área de distribuição) seria o mais plausível (Fig. 9). A seleção natural seria bem mais efetiva entre populações do que no interior delas. Em síntese, o simples fato de haver uma explicação alternativa para o gradualismo filético já indica uma ruptura epistemológica dentro do evolucionismo moderno. Durante certo tempo houve uma batalha 
no campo ideológico na sustentação de um ou outro modelo. $O$ fato é que a comprovação de ambos depende da disponibilidade de dados quantitativos envolvendo estratos e seus fósseis. Nas histórias dos táxons, há instantes, tanto de gradualismo como de pontuísmo.

Figura 8. Pontuísmo e sua relação com a existência de linhagens generalista e especialista. Em geral, a primeira ocorre na base dos cladogramas enquanto que a segunda, no ápice.

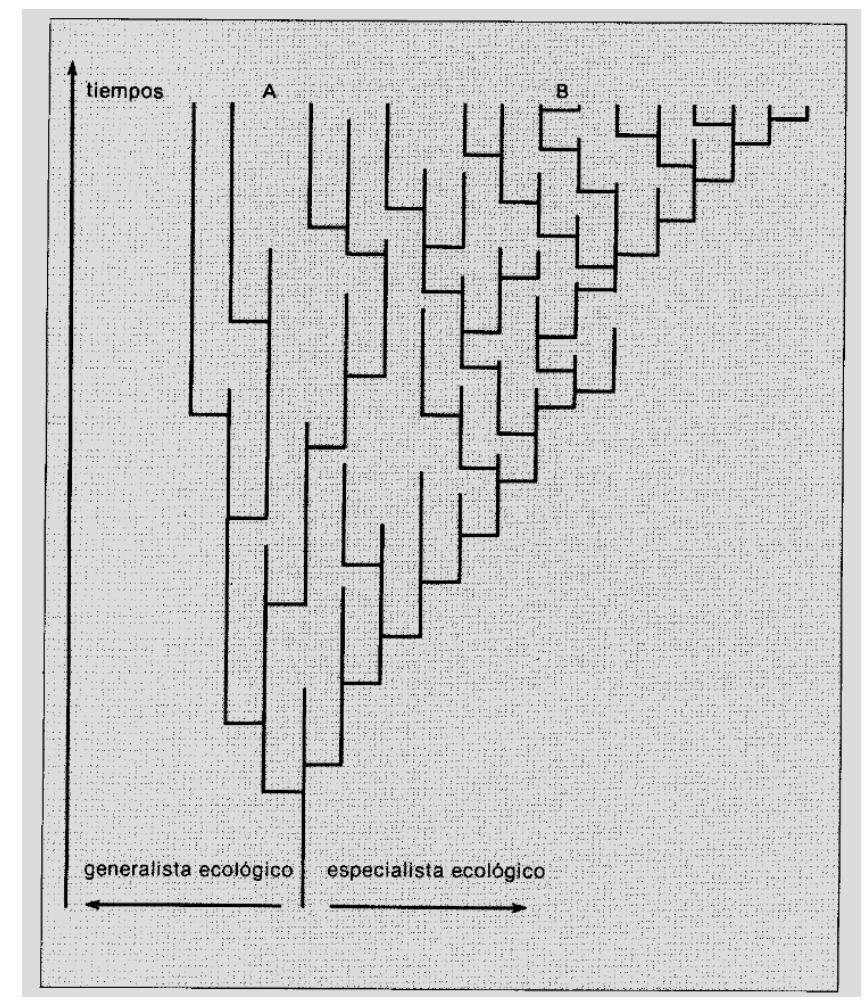

Fonte: Retirado de Eldredge (1983).

(d) Indivíduo como unidade de atuação da seleção natural. - Desde o tempo de Darwin, manteve-se a crença que a seleção natural atuaria sobre indivíduos que competem entre si por recursos, sendo considerado melhor sucedido o que deixa maior número de descendentes. A genética emergente indicou a seleção fenotípica como a melhor explicação. A proposta se manteve inabalável por bom tempo. Mas, na década de 1960, a proposta de seleção de grupo passou a ter certa aceitação (cf. LÁZARO, 2000), caindo logo em desuso pela ação dos darwinistas tradicionais (WILLIAMS, 1966; LEWONTIN,1970). A partir da década de 1950, com a revolução da biologia molecular, tendo os genes como centro das atenções, não 
tardou a se estruturar uma proposta que esses seriam a própria unidade de ação da seleção natural. No entanto, a partir da década de 1970, houve uma tendência em prol de uma visão holística (pluralista), a princípio encabeçada por certos paleontólogos e sistematas (cf. ELDREDGE, 1985). Dessa postura, apareceu uma proposta de seleção hierárquica, baseada em níveis diferentes de ação da seleção natural (GOULD, 1977, 2002) e adotada por macroevolucionistas. Recentemente, a epigenética - estudo voltado para a herança além da ação primária gênica via seleção natural - tomou as rédeas a ponto de indicar as redes gênicas, com interações complexas de genes pleiotrópicos em associação com o ambiente e proteínas específicas, seriam as unidades de atuação da seleção natural (JABLONKA e LAMB, 2010).

Figura 9. A dinâmica dos isolados periféricos.

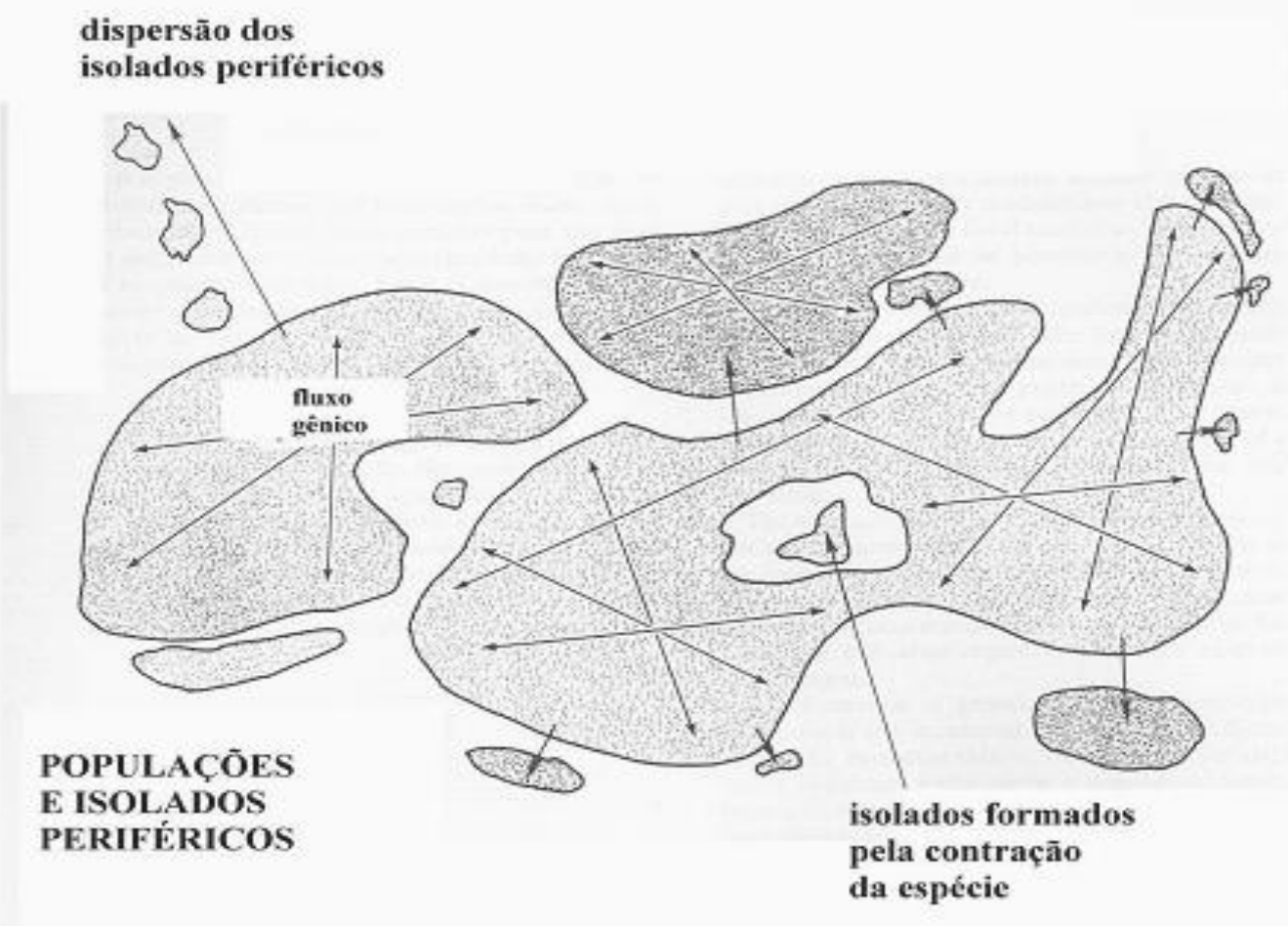

Fonte: Modificado de Bock (1979).

(e) Herança linear e modular: variabilidade, seleção e adaptação - O sistema de herança genético endossado pela Neosíntese é modular e linear. Envolve um processo de cópia independente do conteúdo, com informação codificada e variabilidade ilimitada. Em síntese, mutações aleatórias isoladas exercem ação sobre os passivos genes. Dependendo dos efeitos 
benéficos, a seleção natural realiza a triagem e o acúmulo acarreta mudança no fenótipo levando à adaptação. E a competição, por sua vez, está diretamente associada ao sucesso reprodutivo.

Porém, a visão epigenética contemporânea levou a uma decisiva reavaliação (JABLONKA e LAMB, 2010; PIGLIUCCI e MÜLLER, 2010). Alternativas microevolutivas para a seleção natural foram detectadas: epigenética, flexibilidade fenotípica e construção de nicho (cf. ODLING-SMEE, 2010, PIGLIUCCI, 2010, MULLER, 2010). Variabilidade e novidade evolutiva são aspectos diferentes e complementares. Dentro da variabilidade disponível, coopção e acomodação de traços genéticos contribuem para a flexibilidade fenotípica de modo a permitir finos ajustes promovidos pela seleção natural sobre redes de interação gênicas e não sobre genes isolados. O efeito dos genes no sucesso reprodutivo revelou-se não acumulativo, contrariando a visão gradualista tradicional. Assim, desenvolvimento e ambiente oferecem influências recíprocas, de modo que dois fenótipos no mesmo ambiente podem ser expressos de formas inteiramente diferentes. A evolubilidade depende do quanto a seleção natural pode "enxergar" a estrutura em questão a ser trabalhada, mantendo-a ou modelando-a. Dependendo das restrições (i.e., constraints) existentes, pode ser até inócua. De fato, mutações ocorrem, mas podem receber controle prévio ao nível celular, não sendo tão aleatória quanto se pensava. Desde o tempo de Conrad Waddington (1905-1975), a herança de "caracteres adquiridos" tem sido revisada e os conceitos de canalização e assimilação gênica foram introduzidos (e.g., WADDINGTON, 1957). A canalização ocorre devido à indução ambiental, que pode ativar a atividade gênica numa certa direção, levando à “aquisição de caracteres”. Logo a rede gênica passaria a ter evolubilidade, sendo assimilada nas próximas gerações. A teoria da construção de nicho também mostra que os organismos não são tão passivos às imposições ambientais (ODLING-SMEE, 2010). Na passagem da condição de "caráter adquirido" para a de evolubilidade, o organismo também modifica o próprio nicho, alterando as pressões seletivas. Assim, novas combinações passam a ser visíveis e modeladas pela seleção natural seguindo nova direção (WAGNER e DRAGHI, 2010).

(f) Programa adaptacionista - Na Neosíntese tradicional dá-se maior peso maior para a seleção natural como mecanismo evolutivo (Fig. 10). Seu papel na geração das adaptações é indiscutível. Porém, aos poucos, desenvolveu-se uma linha de pensamento reducionista - o programa adaptacionista - indicando que o organismo pode ser decomposto 
em diversos traços adaptativos independentes (MAYR, 1970). O programa se estendeu ao nível genético com o ufanismo da indicação do gene como agente causal para diferentes aspectos dos seres vivos (e.g., gene da homossexualidade, da obesidade). Para piorar, houve abertura para atitudes pseudocientíficas de todos os lados, até por parte de cientistas não muito familiarizados com questões lidadas pelos geneticistas. Na década de 1970, o programa adaptacionista foi confrontado (GOULD e LEWONTIN, 1979). Ao nível genético, a identificação de complexas redes gênicas e seus produtos também apontou direção contrária. No contexto filosófico, houve a troca gradual de uma perspectiva reducionista por uma holística - a que vê a entidade como um todo histórico e funcionalmente integrado. Para tanto, certos autores (ELDREDGE, 1983; GOULD, 2002) demonstraram a relevância de restrições evolutivas (e.g., padrões ontogenéticos, limitações físicas, alometria) como alternativas para a seleção natural em diferentes casos de interesse. Na revelação da forma ao longo do tempo (i.e., ontogenia e filogenia), aspectos adaptativos são acompanhados de outros não adaptativos ou neutros, contribuindo para a modelagem do todo. E aspectos originalmente adaptativos, com estrutura e função correlacionadas, podem sofrer "desvio de função", independentes da ação da seleção natural, constituindo as chamadas exaptações. Um exemplo bastante utilizado é aquele da história das penas na linhagem dos Dinosauria (incluindo as Aves). Elas surgiram como uma adaptação para a manutenção da temperatura corporal, mas foram cooptadas para uma nova função -o voo-, por processo não direcional.

Figura 10. Programa adaptacionista e visão alternativa pluralista.

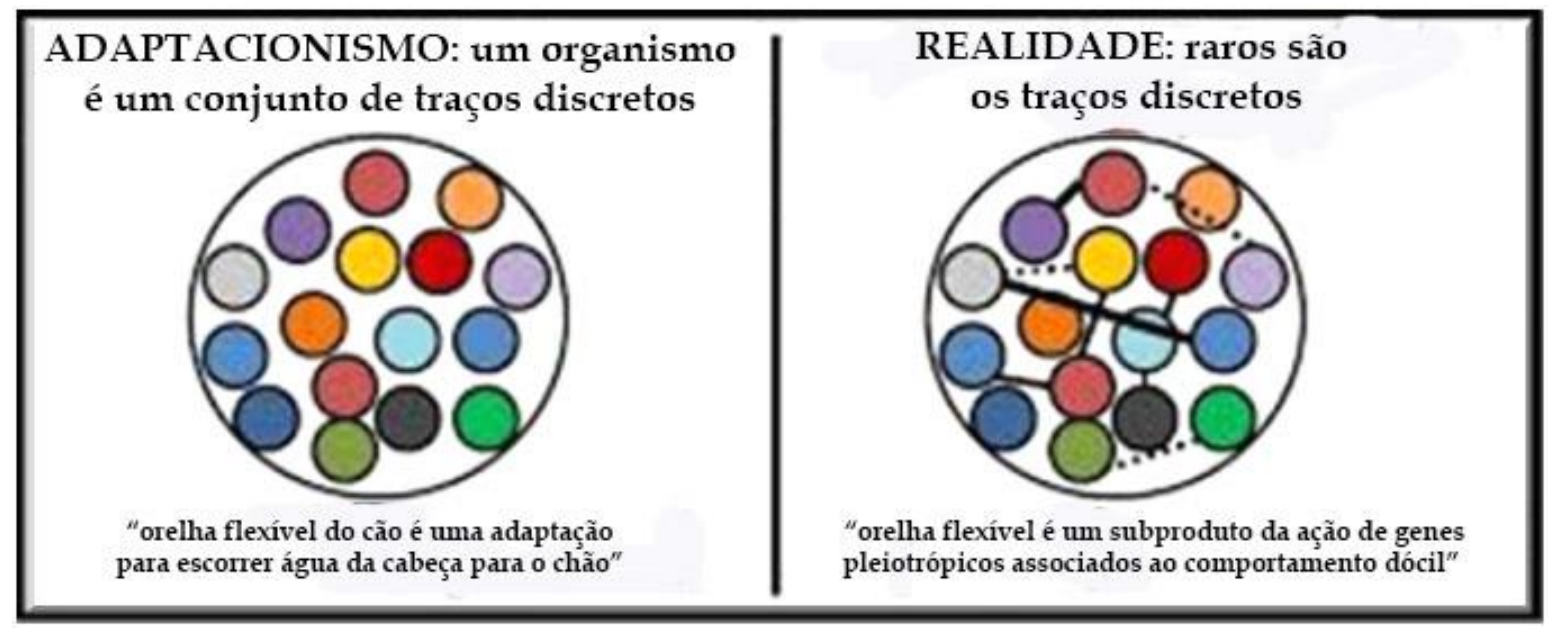

Fonte: Adaptado de diversos autores. 
(g) Biogeografia dispersionista. - A biogeografia darwinista levava em conta o conceito de espaço absoluto - um cenário em que continentes, ao longo da história da Terra, sempre estiveram nas mesmas posições em que se encontram nos mapas atuais (UBILLA, 2000). Para alguns naturalistas extensionistas [e.g., o botânico Joseph Dalton Hooker (18171911)], pontes de terra associadas a transgressões e regressões marinhas em períodos pretéritos facilitariam expansões e contrações de áreas de distribuição dos seres vivos. Extinções em regiões intermediárias contribuiriam para os isolamentos subsequentes. Ao contrário, Darwin, era naturalista permanenticista, ou seja, não acreditava nas pontes de terra. Apostava nas adaptações particulares de plantas e animais para cruzarem grandes extensões oceânicas. Seja como for, rotas de dispersão a partir de restritos centros de origem explicariam padrões de distribuição geográfica à longa distância (SIMPSON, 1965). Na década de 1960, o quadro pouco mudou, mesmo com o advento da teoria da deriva continental por tectônica de placas. Uma ruptura epistemológica começou com o idiossincrásico botânico ítalo-americano Léon Croizat (1898-1982) pela introdução do conceito de espaço relativo na biogeografia em substituição ao de espaço absoluto (MORRONE, 2000, 2009). As histórias biótica e geológica constituem uma só história, dinâmica e indissociável. Por outro lado, Croizat resgatou o conceito de vicariância como uma alternativa para a dispersão saltatória (e.g., CROIZAT, 1964). Na história biogeográfica dos táxons, distinguiu duas etapas: (a) mobilismo, em que as áreas de distribuição de táxons não relacionados se expandem conjuntamente (i.e., geodispersão) no espaço geográfico pela ineficácia ou inexistência de uma barreira. Uma vez estabilizada a distribuição no espaço geográfico tem-se a fase de imobilismo. Então, a biota torna-se sujeita à ação de fatores ambientais que podem levar a quebra na continuidade espacial do conjunto, ou seja, a vicariância. As críticas de Croizat ao darwinismo instigaram a criação de novos programas de investigação científica para a biogeografia histórica e a biologia evolutiva.

(h) Sistemática gradista. - De Darwin até a década de 1960, a prática de reconstrução da árvore filogenética era uma atividade bastante subjetiva e intuitiva (SIMPSON, 1953, 1971; ELDREDGE, 1985; GOULD, 2000). Mesmo reconhecendo que só homologias se prestam à recuperação das relações de parentesco (mesmo carecendo de método explícito para separar homologia de não-homologia), os sistematas evolucionistas admitiam o uso de anagênese e cladogênese, na classificação biológica, discriminando grados e clados. Grados são níveis de organização estrutural alcançados na trajetória de uma linhagem evolutiva. Nesse contexto, fósseis seriam indispensáveis nos estudos macroevolutivos e tratados como ancestrais em 
potencial. As relações entre supostos ancestrais e seus descendentes era feita, na prática, por similaridades entre fósseis e viventes associada com o tempo geológico. Os conceitos de elo perdido e fóssil vivo são remanescentes dessa prática. Explicações narrativas baseadas na experiência, autoritarismo e subjetivismo eram utilizadas por diferentes especialistas na reconstrução das histórias dos táxons. Certos aspectos considerados homólogos recebiam maior peso no esclarecimento das histórias e seriam indicadores dos grados. No entanto, a inclusão dos grados nas classificações levava a violação de hierarquias completas, não refletindo sistema de grupos inclusos (nested-sets) preditos pela teoria evolutiva (Fig. 12). Com o advento da Sistemática Filogenética de Willi Hennig $(1966,1968)$ a situação mudou (HENNIG, 1968; SMITH,1994; AMORIM, 2011; WHELLER, 2012; WILEY e LIEBERMAN, 2012). A sua proposta foi complementar a teoria evolutiva. Desenvolveu um método explicito de reconstrução de filogenias com base no compartilhamento de novidades evolutivas (sinapomorfias) e discriminação de grupo monofiléticos. Substituiu o esquema de parentesco usual entre os gradistas, envolvendo relação direta ancestral-descendente (equivalente a uma spanning-tree, com objetos ligados diretamente por linhas) por aquela de ancestral comum hipotético mais recente (equivalente a uma árvore de Steinner, sem ligação direta entre os objetos, mas por nós que especificam indiretamente a conexão). A proposta de Hennig pode ser traduzida num enunciado de três itens: dada três espécies, duas estão mais aparentadas entre si se e somente se compartilharem uma ancestral comum que não é aquele compartilhado com uma terceira espécie.

Levando em consideração que numa série de transformação de estruturas homólogas, a condição original (ancestral ou plesiomórfica) é dita primitiva e a modificada dessa, a condição derivada (apomórfica), só o compartilhamento de novidades evolutivas (i.e., sinapomorfia) pode revelar relação de ancestralidade em comum (HENNIG, 1968; WILEY, 1981; AMORIM, 2011). 0 diagrama ramificado que exibe hierarquia de sinapomorfias é o cladograma. Trata-se da mais simples das árvores enraizadas. Indica quem está relacionado com quem e com base em quê. Acrescido outros dados (e.g., calibração temporal na árvore ultramétrica ou dendrograma; taxa de evolução, na árvore aditiva ou filograma; Figs. 12, 13), contribui para o esclarecimento de detalhes da filogenia (PAGE e HOLMES, 1998). Na escolha entre hipóteses de relacionamento expostas pelo cladograma, empregava-se a priori o critério de parcimônia, mas sofisticadas técnicas estatísticas tem ganhado espaço (e.g., análise bayesiana) (WHELLER, 2012).. Por fim, 
os conceitos de elo perdido e fóssil vivo foram demolidos com o cladismo, pelo fato de serem reconhecidos por seletas plesiomorfias (SMITH, 1994).

\section{CONCLUSÕES}

A ciência é a forma do saber que proporcionou melhor conhecimento e domínio do mundo físico (D'ONOFRIO, 1999). Ao reconhecer que o conhecimento nem é absoluto ou definitivo, a ciência dá abertura para a elaboração de criativas conjecturas e arrojadas formas para refutações (POPPER, 1972). Mesmo contaminada com a influência do ambiente em que se desenvolve, a ciência é uma celebração da liberdade de pensamento e expressão (BUNGE, 1985; GEWANDSNAJDER, 1989, 2010).

Há diferentes ciências e métodos científicos. Em extremos opostos de um contínuo, há ciências "hard" e "soft" (PLIGIUCCI, 2013). O julgamento dos méritos do conhecimento obtido é algo subjetivo. A eleição de um critério como potencial demarcador de ciência esbarra com uma série de limitações.

O critério de vulnerabilidade de Elliott Sober (e.g., SOBER, 2008) apresenta vantagens na investigação de indivíduos naturais, objetos de estudo das ciências históricas. Porém, uma aplicação cética revela que as justificativas podem levar a regressão infinita.

Dentro da proposta de metodologia de programas de pesquisa científica, prescrita por Imre Lakatos (1978), a teoria evolutiva se revela como um programa progressivo, gerando predições testáveis. Propostas alternativas, encabeçadas por um “criacionismo científico", não se sustentam pela total falta de evidências e predições testáveis.

Uma vez que evolução é história, por corolário há uma única filogenia de vida para o planeta Terra. Mesmo constituída de sequências de fatos únicos, situações de interação organismo-ambiente geram respostas similares, compondo padrões replicados. E a reconstrução dessa história envolve a escolha entre hipóteses rivais que melhor explicam os fatos. Permanece aquela que, apesar de circunstancial, apresenta maior capacidade de explicação de eventos passados. 
Com todas as críticas e falta de consenso (RUSE, 1983; RIDLEY, 1984, 1986; STERELNY e GRIFFITHS,1999; MORRONE, 2003; SHERMER, 2006, 2011; PIGLIUCCI, 2007; PIGLIUCCI e MÜLLER, 2013), a teoria de evolução por seleção natural de Darwin, representada pela atual Neosíntese, mostra-se resiliente, acomodando novos inputs e acumulando evidências favoráveis, permanecendo viva (FUTUYMA,1993, 1995; RIDLEY,2006).

Figura 11. A Pan-biogeografia de Léon Croizat. Com ela, introduziu-se a visão de espaço geográfico relativo, com mudanças na configuração dos continentes e das biotas associadas ao longo da história da Terra em oposição à visão darwinista tradicional que endossava o espaço absoluto (continentes estáticos e permanentes desde a origem remota). A história dos seres vivos e de suas localidades é única e indissociável. O método consiste na conexão de áreas de distribuição geográfica através de linhas seguindo o critério de mínima distância (i.e., na teoria dos grafos, uma árvore spanning-tree). Com a coincidência na sobreposição das linhas (i.e., traços individuais) obtêm-se traços generalizados, indicados de história comum atribuída à vicariância ou geodispersão em contraste com a dispersão saltatória, relativa à história taxonômica particular. Note que 1-5 são os nós biogeográficos, áreas de complexidade tectônica e biológica, reconhecidos pela congruência de traços generalizados. Croizat também deu ênfase a fatores alternativos à seleção natural na sua concepção de ortogênese na explicação da mudança da forma na interface tempo-espaço, tais como restrições evolutivas e correlação de caracteres de evolucionistas contemporâneos.

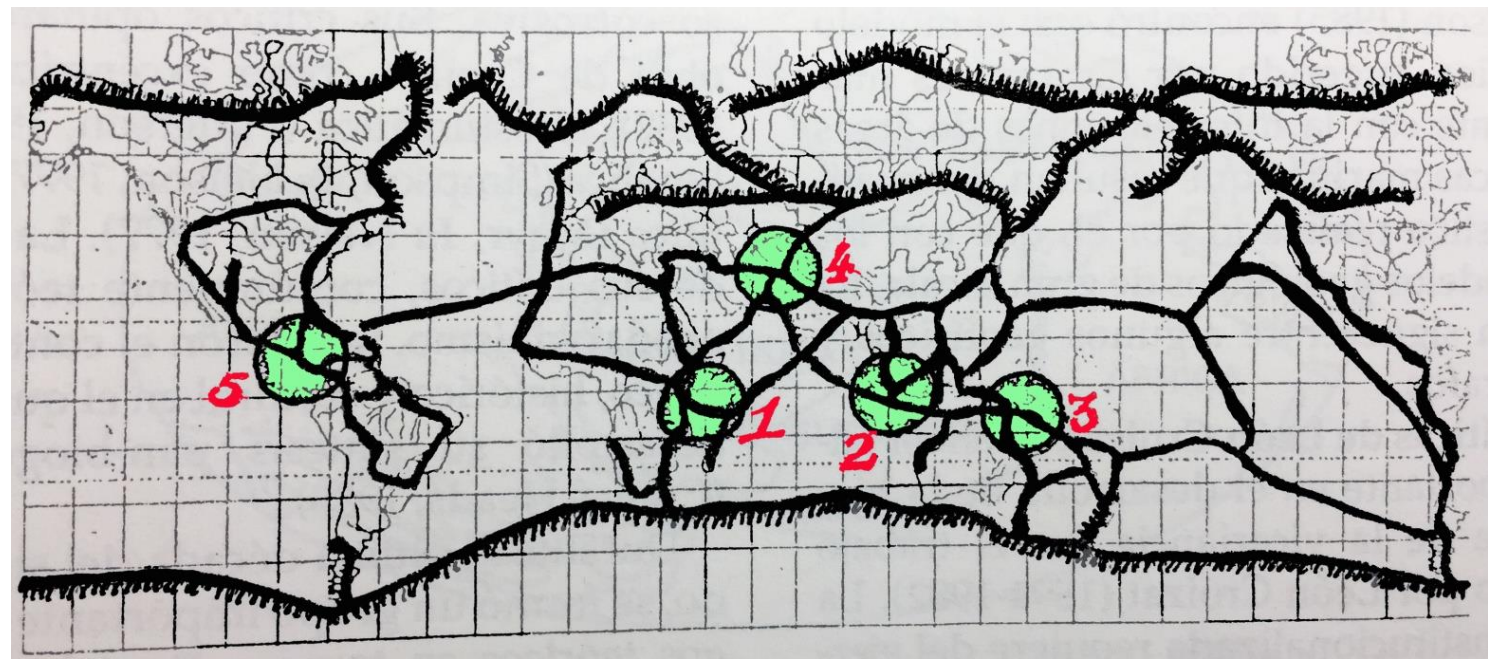

Fonte: Modificado de Croizat (1964). 
Figura 12. Classificação gradista e seus critérios. Na classificação gradista tanto anagênese quanto cladogênese são levadas em consideração. No caso abaixo, critérios como descontinuidade morfológica (disparidades entre dois grupos taxonômicos), conjunto de nichos ecológicos similares (modos de vida semelhantes), grande diversidade (riqueza de espécies) e monofiletismo mínimo (i.e., merofiletismo, espécie ancestral, mas não necessariamente todos seus descendentes) podem servir de justificativa para se colocar na classificação táxons no mesmo nível hierárquico. No entanto, o procedimento não espelha a relação evolutiva que envolve grupos-dentrode-grupos, violando assim a hierarquia natural.

\section{Classificação gradista}

Classe Reptilia

Classe Aves

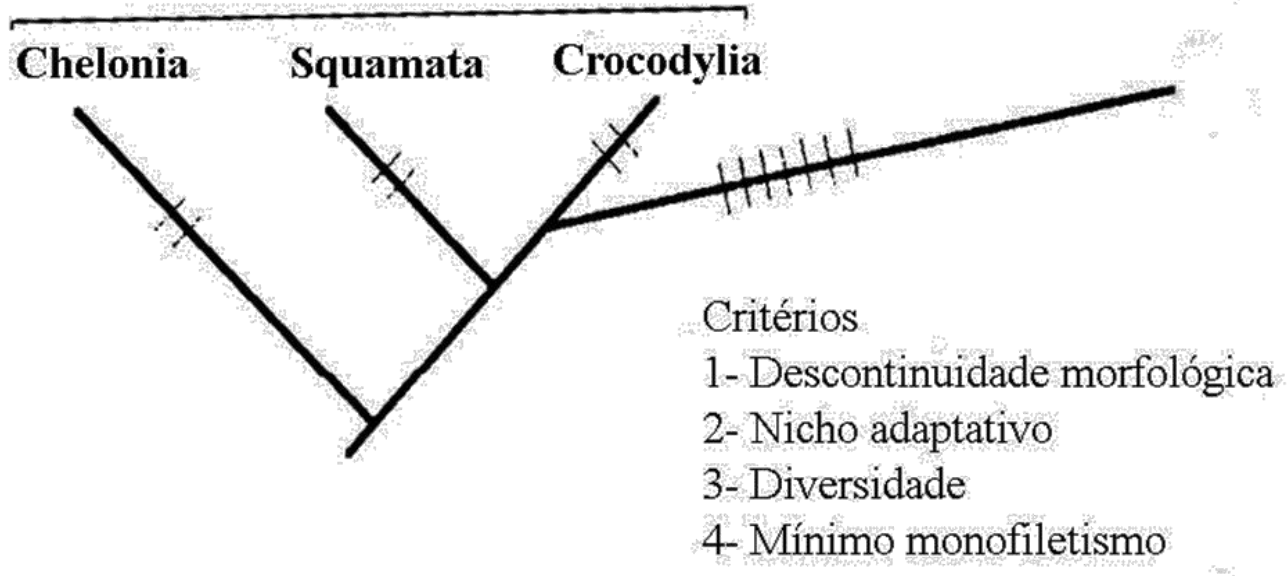

Fonte: Modificado de Matile et al. (1991). 
Figura 13. Diferentes tipos de árvores. Aquela dita não-enraizada é a que expressa relação entre os objetos, mas sem exibir polarização (i.e., discriminação de qual condição de um caráter é primitiva ou derivada). Ao se polarizar e simultaneamente fixar o grupo-externo (aquele eleito na análise cladística para comparação), obtém-se automaticamente o cladograma. No caso de se acrescentar novas informações ao cladograma, tais como taxas de evolução e calibragem temporal têm-se respectivamente, árvores aditiva (i.e., filograma) e ultramétrica (i.e., dendrograma). Por fim, quando ancestrais são apontados e processos filogenéticos e evolutivos acrescentados, tem-se uma filogenia.

\section{Tipos de árvores}

Filogenia

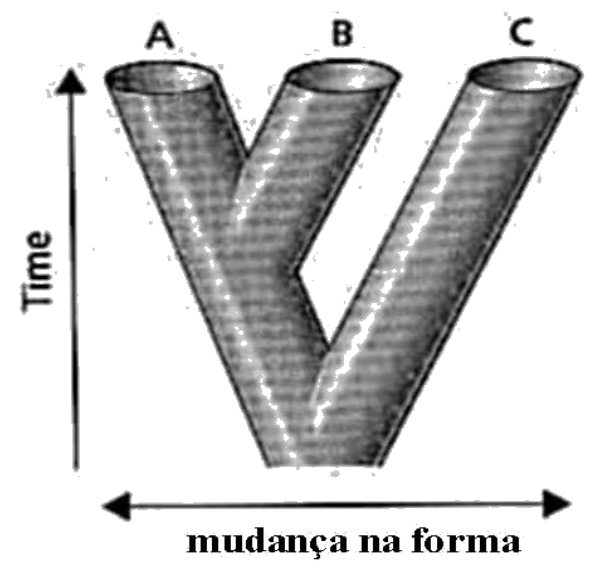

árvore sem raiz

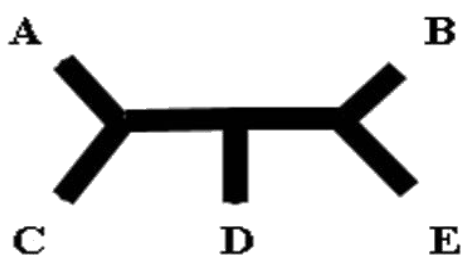

cladograma

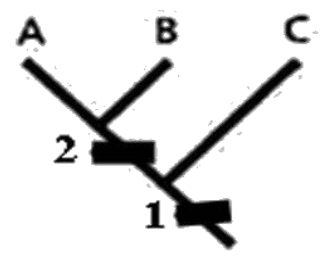

árvore aditiva

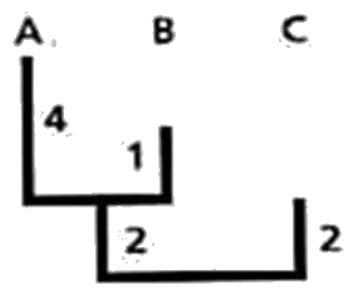

árvore ultramétrica

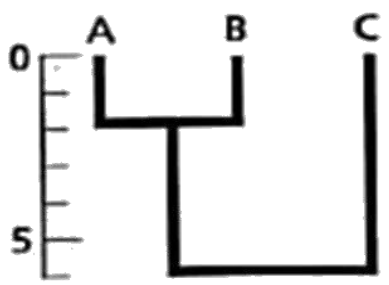

Fonte: Modificado de Page e Holmes (1998). 
Figura 14. Filogenia dos primatas. Com a comparação de sequências de DNA entre indivíduos de espécies diferentes recuperam-se as relações de ancestralidade comum de modo a representá-las sob a forma de árvore. A árvore da figura está calibrada com eixo de tempo (cf. DONOGHUE e BENTON, 2007). H. sapiens é tratada como qualquer outra espécie e aparece como grupo-irmão do chimpanzé (Pan troglodytes). A divergência entre as duas linhagens é recente: ca. 7 Ma. Note que H. sapiens compartilha com os demais primatas ancestrais, em diversos pontos da árvore, diferentes aspectos e propriedades. Logo, macaco é um termo bastante vago, pois inclui primatas mais avançados que Lemuriformes, Lorisiiformes e Tarsiiformes. Mico-leão, babuíno, gibão, orangotango, gorila e chimpanzé são macacos antropoides. E nós (H. sapiens) somos upgrade de macaco. A figura mostra que acima de Tarsiidae há seis nós no cladograma. Neles estariam ancestrais com aspecto de macaco. Porém, nenhuma espécie de macaco vivente é candidato a ser nosso ancestral imediato. Cada macaco atual é sobrevivente da sua própria linhagem; muitas outras espécies se extinguiram na história de suas linhagens e algumas, por sorte, são conhecidas de fósseis. Os macacos viventes são nossos "primos". Ao se dizer que somos mamíferos, isso implica que tivemos um ancestral comum não mais reptiliano que pela primeira vez apresentou aspectos distintivos para aquilo que convencionalmente chamamos de "mamífero". E sem dúvida, herdou e reteve aspectos muito primitivos compartilhados com protocordados, peixes, anfíbios etc. Esse ancestral mamífero possuía aspectos mais próximos de um ornitorrinco do que dos cangurus, ratos ou primatas (TATTERSALL, 2013). Em suma, a expressão "veio de..." é um argumento tipicamente evolucionista, ao contrário de "criado por..." que só faz sentido em contexto criacionista.

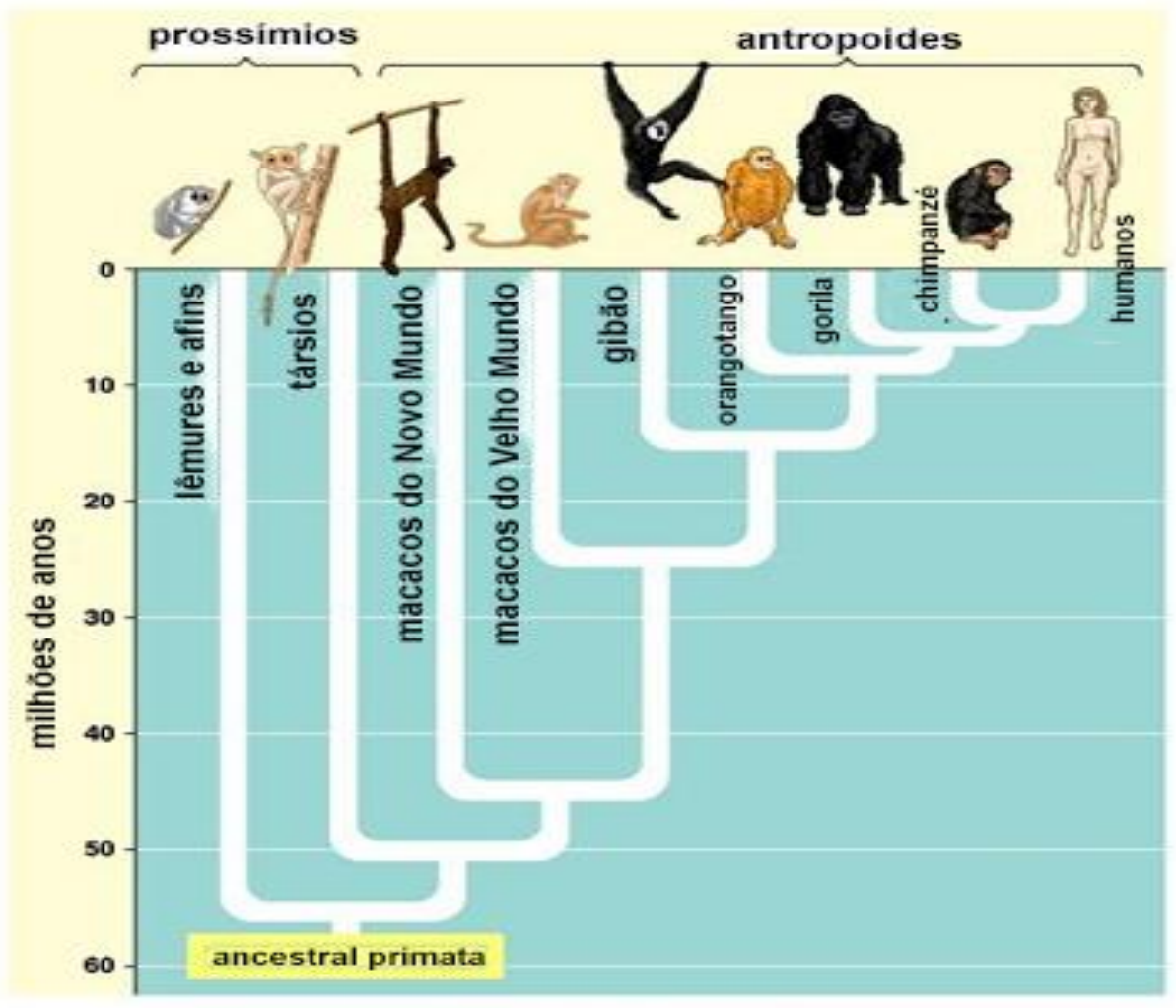

Fonte: Modificado de Pearson Educations. 


\section{AGRADECIMENTOS}

Agradecemos a Josimar Ribeiro de Almeida, Carlos Henrique Monteiro e Clarissa Canedo pela leitura crítica do texto e sugestões. Anja Cerri revisou os resumos.

\section{REFERÊNCIAS}

ALMEIDA, C.A.S.; BONVICINO, C.R.; LACHTERMACHER,M.; MOREIRA, M.A.M.; OLÍCIO, R.; SEUÁNEZ, H.N. Técnicas de avaliação da diversidade genética. p.268-294. In: I. Gray e B. Dias (orgs.) Conservação da biodiversidade em ecossistemas tropicais: avanços conceituais e revisão de novas metodologias de avaliação e monitoramento. Petrópolis: Ed. Vozes, 2001.

AMORIM, D.S. Fundamentos de Sistemática Filogenética. Ribeirão Preto: Holos, 2011.

AVISE, J.C. Phylogeography: The history and formation of species. Cambridge: Harvard University press, 2000 .

BEGOSSI, A. 1993. Ecologia Humana: Um Enfoque Das Relações Homem-Ambiente. Interciencia 18(1): 121-132.

BLEIDORN, C. Phylogenomics: An Introduction. Cham: Springer, 2017.

BOCK, W.J. The synthetic explanation of macroevolutionary change - a reductionistic approach. In: J.H. Schwartz and H.B. Rollins (eds.), Models and Methodologies in Evolutionary Theory. Bull. Carnegie Mus. Nat. Hist. 13: 20-69, 1979.

BOWLER, P. Evolution: the history of an idea. 2. ed. Berkeley: University of California, 1989.

BUNGE, M. La Investigación Científica. 2ª ed. Barcelona: Ariel, 1985.

CAPLAN, A. The nature of darwinian explanation: is darwinian evolutionary theory scientific? pp. 24-39. In: Godfrey, L.R. What Darwin began. Boston: Allyn e Bacon, 1987.

CARROLL, S.B. Endless Forms Most Beautiful. London: Quercus Publishing, 2011

CARROLL, S.B. The making of the fittest: DNA and the ultimate forensic record of Evolution. New York: W.W. Norton and Co., 2006.

CHALMERS, A. O que é Ciência afinal? São Paulo: Editora Brasiliense, 1993.

COYNE, J.E. Por que Evolução é uma verdade. São Paulo: JSN Editores, 2014.

COYNE, J.E; ORR,H.A. Speciation. Sunderland, MA: Sinauer, 2004.

CROIZAT, L. Space, time and form: the biological synthesis. [Publicado pelo autor] Caracas, 1964.

D’ONOFRIO, S. Metodologia do Trabalho Intelectual. São Paulo: Editora Atlas, 1999.

DARWIN, C. R. Origem das Espécies. Belo Horizonte: Itatiaia. [1859] 2002. 
DAWKINS, R. O gene egoísta. Trad. Fernanda Ravagnani. São Paulo: Companhia das Letras, 1976.

DAWKINS, R. o relojoeiro cego: A teoria da evolução contra o desígnio divino. São Paulo: Companhia das Letras, 2001.

DAWKINS, R. Deus, um delírio. São Paulo: Companhia das Letras, 2007.

DENNET, D.C. Darwin's dangerous Idea: evolution and the meaning of life. New York: Simon e Schuster, 1995.

DOBZHANSKY, T. Nothing in biology makes sense except in the light of evolution. The American Biology Teacher, 35: 125-129, 1973.

DOLITTLE, W.F. Phylogenetic classification and the universal tree. Science, 284:2124-2128, 1999.

DONOGHUE, P.C.J.; BENTON, M.J. Rocks and clocks: calibrating the Tree of Life using fossils and molecules. Trends in Ecology and Evolution, 22(8): 424-431, 2007.

EISELEY, L. Darwin's century: evolution and the men who discovered it. New York: Doubleday, 1958.

ELDREDGE, N. Macroevolución. Mundo Científico, 2(16): 792-803, 1983.

ELDREDGE, N. Unfinished Synthesis: Biological hierarchies and modern evolutionary thought. New York: Oxford University Press, 1985.

ELDREDGE, N. Macroevolutionary Dynamics: Species, Niches and Adaptive Peaks. New York: McGraw-Hill, 1989.

ELDREDGE, N. Reinventing Darwin: The great evolutionary debate. London: Orion Books, 1995.

ELDREDGE, N. O Triunfo da Evolução. Ribeirão Preto: FUNPEC, 2010.

ENDLER, J.A. Geographic variation, speciation, and clines. Princeton, NJ: Princeton University Press, 1977.

ENDLER, J.A. Natural selection in the wild. Princeton, NJ: Princeton University Press, 1986.

FERRAGUTI, M.; C. CASTELLACCI. Evoluzione: Modelli e Processi. Milão: Pearson Italia, 2011

FIGUEIREDO, F.J.; OLIVEIRA, L.A. Filosofia da Ciência e Evolução: Parte 1. Sustinere (in press).

FIGUEIREDO, F.J.; OLIVEIRA, L.A. Filosofia da Ciência e Evolução: Parte 2. Sustinere (in press).

FOREY, P. (Ed.) The Evolving Biosphere: Chance, change and challenge. London: BMNH-Cambridge University Press, 1981.

FUTUYMA, D.J. Biologia Evolutiva. Ribeirão Preto: SBG, 1993.

FUTUYMA, D.J. Science on Trial: the case for evolution. Sunderland, MA: Sinauer, 1995.

GEWANDSZNAJDER, F. O que é o método científico. São Paulo: Pioneira, 1989.

GEWANDSZNAJDER, F. O método nas ciências naturais. São Paulo, 2010.

GOULD, S.J. Ontogeny and Phylogeny. Cambridge: Belcknap Harvard, 1977.

GOULD, S.J. The Structure of Evolutionary Theory. Cambridge: Belkenap Press, 2002. 
GOULD, S.J.; LEWONTIN, R. The spandrels of San Marco and the Panglossian paradigm: a critique of the adaptationist program. Proc. R. Soc. London Ser.B, 205: 581-598, 1979.

HARVEY, P.H.; PAGEL, M.D. The comparative method in evolutionary biology. Oxford; Oxford university Press, 1993.

HAWKING, S; MLODINOW, L. o Grande Projeto: Novas Respostas para as Questões Definitivas da Vida. Rio de Janeiro: Editora Nova Fronteira, 2011.

HEAMS, T.; HUNEMAN, P.; LECOINTRE, G.; SILBERSTEIN, M. Handbook of Evolutionary

Thinking in the Sciences. Dordrecht: Springer, 2015.

HENNIG, W. Elementos de Sistemática Filogenética. Buenos Aires; EDUEBA, 1968.

HULL, D. Filosofia da Ciência Biológica. Rio de Janeiro: Zahar Editores, 1974.

HULL, D. Science as a Process: An Evolutionary Account of the Social and Conceptual Development of Science. Chicago and London: The University of Chicago press, 1987.

HULL, D.; RUSE, M. (eds.). The Philosophy of Biology. Oxford and New York: Oxford University Press, 1998.

JABLONKA, E.; M.J. LAMB. Evolução em quarto dimensões: DNA, comportamento e a história da vida. São Paulo: Companhia das Letras, 2010.

JEFFREYS, A.J.; MORTON, D.B. DNA fingerprints of dogs and cats. Animal. Gen., 18: 1-15.

LAKATOS, I. The Methodology of scientific research programmes. Philosophical Papers, vol. 1. J. Worrall e G. Currie (eds.). Cambridge: Cambridge University Press, 1978.

LAKATOS, I. Falsification and the Methodology of scientific. Research Programmes. p. 91-196. In: LAKATOS, I.; MUSGRAVE, A. (eds.) Criticism and the Growth of Knowledge. Cambridge: Cambridge University Press, 1987.

LANDIM, M.I.; MOREIRA, C.R. (eds.) Charles Darwin: Em um futuro não tão distante. São Paulo: Instituto Sangari, 2009.

LÁZARO, M. ¿Em qué nivel opera la selección natural? Discusiones em torno al problema de las unidades de selección. p.226-242. In: C. Altuna e M. Ubilla (eds.) El prisma de la Evolución: A 140 años de "El origen de las espécies". Montevideo: DIRAC-Facultad de Ciencias, 2000.

LEWONTIN, R. Adaptation. Sci. Am., 239: 156-69, 1979.

LEWONTIN, R. A tripla hélice: gene, organismo e ambiente. São Paulo: Companhia das Letras, 2002.

LEWONTIN, R. C. The units of selection. Annu. Rev. Ecol. Syst., 1:1-18, 1970.

MACBETH, N. Darwin retried: an appeal to reason. Boston, Gambit Incorporated, 1971.

MAGEE, B. As Ideias de Popper. São Paulo: Cultrix, 1974.

MAGEE, B. The Story of Philosophy. New York, Dorling Kindersley, 1998.

MARTINEZ, S.; BARAHONA,A.(eds.) Historia y explicación en biologia. Mexico: UNAM-Fondo de Cultura econõmico, 1998.

MATILE, L.; TASSY, P.; GOUJET, D. Introduction a la Systematique Zoologique. Paris: Societé française de Systématique, 1991. 
MAYNARD SMITH, J.; SZATHMÁRY, E. The major transitions in Evolution. Oxford; Oxford University Press, 1997.

MAYNARD SMITH, J.; SZATHMÁRY, E. As Origens da Vida: Do nascimento da vida às origens da linguagem. Lisboa: Gradiva, 2007.

MAYR, E. Populations, species and Evolution. Cambridge: Harvard University Press, 1970.

MAYR, E. Systematics and the Origin of Species. New York: Columbia University Press, [1942] 1982.

MAYR, E. O desenvolvimento do pensamento biológico. Brasília: Editora Unb, 1998.

MAYR, E. What Evolution is. New York: Basic Books, 2001.

MAYR, E. Biologia, ciência única. São Paulo: Companhia das Letras, 2005.

MAYR, E. Uma ampla discussão: Charles Darwin e a gênese do moderno pensamento evolucionário. Ribeirão Preto: FUNPEC, 2006.

MAYR, E. Isto é biologia: a ciência do mundo vivo. São Paulo: Companhia das Letras, 2008.

MAYR, E.; PROVINE, W.B. The evolutionary synthesis: perspectives on the unification of biology. Cambridge: Harvard University Press, 1982.

MEYER, D.; EL-HAINI, C.N. Evolução: o sentido da biologia. São Paulo: UNESP, 2005.

MORRONE, J.J. Entre el escarnio y el encomio: Léon Croizat y la panbiogeografía. Interciencia 5: 41-47, 2000.

MORRONE, J.J. ¿Quién le teme al darwinismo? Ciencia: 78-88, 2003.

MORRONE, J.J. Evolutionary Biogeography: An integrative approach with case studies. New York: Columbia, 2009.

MULCAHY, D.G. 2008. Phylogeography and species boundaries of the western North American Nightsnake (Hypsiglena torquata): Revisiting the subspecies concept. Mol. Phylogen. and Evol. 46: 1095-1115, 2008.

MÜLLER, G.B. Eigenetic innovation. p.307-332. In: M. Pigliucci e G. Müller (eds.) Evolution: The extended synthesis. Cambridge: MIT Press, 2010.

NAS (National Academy of Sciences of the USA). Teaching about evolution and the nature of science. Washington, DC: National Academies press, 1998.

NEIVA, E. O Racionalismo Crítico de Popper. Rio de Janeiro: Livraria Francisco Alves, 1998.

NELSON, G.J. Outline of a theory of comparative biology. Syst. Zool., 19:373-384, 1970.

NELSON, G.J. Species and taxa: systematics and evolution. p. 60-81. In: Otte, D.; Endler, J.A. (eds.) Speciation and its consequences. Sunderland, MA: Sinauer, 1989.

NELSON, G.J.; LADIGES, P. 2009. Biogeography and the molecular dating game: a futile revival of fenetics? Bull. Soc. Geol. Fr., 180(1): 39-43.

NELSON, G.J; PLATNICK, N. Systematics and Biogeography: Cladistics and Vicariance. New York: Columbia, 1981.

ODLING-SMEE, J. Niche inheritance. p.175-208. In: M. Pigliucci e G. Müller (eds.) Evolution: The extended synthesis. Cambridge: MIT Press, 2010. 
OLIVEIRA, C. Marcadores genéticos. Bol. SBI, Rio de Janeiro, 100: 23-29, 2010.

OLSON, E.C.; C.F. BRUNK. The evolutionary synthesis today: an essay on paleontology and molecular biology. Contributions to Geology, Special Paper 3: 351-361, 1986.

OTTE, D.; ENDLER, J.A. (eds.) Speciation and its consequences. Sunderland, MA: Sinauer, 1989.

PAGE, R.D.M.; HOLMES, E.C. Molecular Evolution: A phylogenetic approach. Oxford: Blackwell Science, 1998.

PATTERSON, C. Evolution. New York: Cornell University Press, 1978.

PETERS, E.K. No Stone Unturned: Reasoning about Rocks and Fossils. New York: W.H. Freeman, 1996.

PETERS, R. A Critique for Ecology. Cambridge: Cambridge University Press, 1989.

PIGLIUCCI, M. Do we need and extended evolutionary synthesis? Evolution 61: 2743-2749, 2007.

PIGLIUCCI, M. Phenotypic plasticity. p.355-378. In: M. Pigliucci e G. Müller (eds.) Evolution: The extended synthesis. Cambridge: MIT Press, 2010.

PIGLIUCCI, M. Nonsense on stilts: how to tell science from bunk. Chicago: Chicago University press, 2013.

PIGLIUCCI, M.; M. BOUDRY (eds.) Philosophy of Pseudoscience. Chicago: Chicago University Press, 2013.

PIGLIUCCI, M.; MÜLLER,G.B. (eds.) Evolution: The extended synthesis. Cambridge; MIT Press, 2010.

POPPER, K. Conjecturas e refutações. Brasília: UnB, 1972.

QUEIROZ, K. 2007. Species concepts and species delimitation. Syst. Biol., 56(6): 879-886.

QUEIROZ, K. e M. DONOGHUE. Phylogenetic systematics and species revisited. Cladistics 6: 83-90, 1990.

RAF, R.A. Ribosomal RNA sequences and the early history of the Metazoa. p.63-74. In: B. Runnegar e J.W. Schopf (orgs.) Molecular Evolution and the Fossil Record. Denver: The Paleontological Society, 1988.

RIDLEY, M. Evolution and Classification: The Reformation of Cladism. New York: Longman, 1986.

RIDLEY, M. La evolución y sus problemas. Madrid: Ediciónes Pirámide, 1987.

RIDLEY, M. Evolução. Porto Alegre: Artemed, 2006.

RIEPPEL, O.C. Fundamentals of Comparative Biology. Basel: Birkhauser Verlag, 1988.

ROSEN, D.E. Fishes from the uplands and intermontane basins of Guatemala: revisionary studies and comparative geography. Bull. Am. Mus. Nat. Hist., 162: 267-376, 1979.

ROSENBERG, A.; McSHEA, D. Philosophy of Biology: A Contemporary Introduction. New York and London: Routledge, 2008.

RUIZ, R.; AYALA, F. J. El Método en las Ciencias: Epistemologia y Darwinismo. México: Fondo de Cultura Económica, 2000.

RUSE, M. Darwin defended: A guide to the evolution controversies. Menlo Park, CA: The Benjamin/Cummings Publs. Co., 1982.

RUSE, M. La Revolución Darwinista. Madrid: Alianza editorial, 1979.

RUSE, M. Levando Darwin a sério. Belo Horizonte: Itatiaia, 1995. 
SHEPPARD, P.M. Natural selection and heredity. London: Hutchinson and Co., 1975.

SHERMER, M. Why Darwin Matters. The Case against Intelligent Design. New York: Henry Holt, 2006.

SHERMER, M. Por que as pessoas acreditam em coisas estranhas? São Paulo: JSN, 2011.

SIMPSON, G.G. Tempo and Mode in Evolution. New York: Columbia University Press, 1944.

SIMPSON, G.G. The major features of Evolution. New York: Columbia University Press, 1953.

SIMPSON, G.G. The geography of evolution. New York: Chilton Co., 1965.

SIMPSON,G.G. Princípios de Taxonomia Animal. Lisboa: Fund.Calouste Gulbenkian, 1971.

SMITH, A.B. Systematics and the fossil record: documenting evolutionary patterns. Oxford: Blackwell, 1994.

SMITH, C.; SULLIVAN, C. I falsi miti dell'evoluzione. Trad. Laura Appiani. Bari: Edizione Dedalo, 2008.

SMITH, P.J. Ceticismo. Rio de Janeiro: Jorge Zahar Editor, 2004.

SOBER, E. The nature of selection: evolutionary theory in philosophical focus. Cambridge: MIT Press, 1984.

SOBER, E. Philosophy of Biology. Boulder, CO: Westview Press, 1993.

SOBER, E. Evidence and Evolution: The Logic behind the Science. Cambridge: Cambridge University Press, 2008 .

SOBER, E. Did Darwin write the Origin backwards? Philosophical Essays on Darwin's Theory. Amherst and New York: Prometheus Books, 2011.

STANLEY, S.M. Macroevolution: Pattern and Process. San Francisco: Freeman and Co., 1979.

STEBBINS, G.L. Processos de evolução orgânica. São Paulo: EDUSP, 1974.

STERELNY, K.; GRIFFITHS, P. Sex and Death: Na Introduction to Philosophy of Biology. Chicago and London: The University of Chicago Press, 1999.

SYKES, B. As sete filhas de Eva. São Paulo: Record, 2003.

TASSY, P. L' árbre à remonter le temps: les recontres de la systématique et de l'évolution. [s.l.], Christian Bourgois Éditeur, 1991.

TATTERSALL, I. Masters of the Planet: The Search for Our Human Origins. New York: Palgrave Macmillan Trade, 2013.

UBILLA, M. Darwin y la distribución geográfica de los organismos. p. 99-111. In: C. Altuna e M. Ubilla (eds.) El prisma de la Evolución: A 140 años de "El origen de las espécies". Montevideo: DIRAC-Facultad de Ciencias, 2000 .

WADDINGTON, C.H. The strategy of the genes. London: Allen e Unwin, 1957.

WAGNER, G.P.; DRAGHI, J. Evolution of evolvability. p. 379-399. In: M. Pigliucci e G. Müller (eds.) Evolution: The extended synthesis. Cambridge: MIT Press, 2010.

WARD, P. O Fim da Evolução: extinções em massa e preservação da biodiversidade. Rio de Janeiro: Editora Campus, 1997. 
WARD, P. Out of thin air: dinosaurs, birds, and earth's ancient atmosphere. Washington, Joseph Henry Press, 2006.

WATSON, J.D. The double helix. New York; Antheneum, 1968.

WATSON, J.D.; CRICK,F.H.C. A structure for deoxyribose nucleic acid. Nature, 171: 737-738, 1953.

WHELLER, W. Systematics: A Course of Lectures. Chichester: Wiley-Blackwell, 2012.

WHITE, M.J.D. Modes of speciation. San Francisco: W.H. Freeman Co., 1978.

WOESE, C. The universal ancestor. Proc. Nat. Acad. Sci., 95(12): 6854-6859, 1998.

WILEY, E.O. Phylogenetics: the Theory and practice of phylogenetic systematics. New York: J. Wiley and Sons, 1981.

WILEY, E.O. Is the evolutionary species fiction? A consideration of classes, individuals and historical entities. Syst. Zool. 29: 76-80, 1980.

WILEY,E.O.; LIEBERMAN, B.S. Phylogenetics; Theory and practice of phylogenetic systematics. New York: J. Wiley, 2011.

WILLIAMS, G.C. Adaptation and Natural Selection. Princeton: Princeton University Press, 1966.

\section{$(\mathrm{cc}) \mathrm{Br}$}

Este trabalho está licenciado com uma Licença Creative Commons - Atribuição 4.0 Internacional. 